\title{
A Critical analysis of Civil Procedure RULES 187 AND 190: STRINGENCY WITHOUT EFFICACY
}

\author{
Peter Bowal and Ben LaU “*
}

In the ongoing effort 10 modernize and improve the civil process, the Alberta Rules of Court were amended in 1999. Afldavits of records are automatically required within a fixed period of time and non-compliance is sanctionable by a virtually automatic right to double costs. This article iraces the genesis of these new, uniquely Albertan procedural rules. then identifies several concerns and critically analyzes them. It concludes that in practice. the five year old amendments generally do not serve to expedite proceedings, reduce litigant or public cosis. facilitate settlement on the substantive merits of the dispute, nor enhance the overall public perception of the administration of civil justice. In fact, they may have the opposite effect from what was intended of encouraging settlement and the prudent use of court time. The authors recommend that the current Alberta Law Reform Institute 's Rules of Court Project should propose rescission of these recem amendments and return 10 the demand model reinforced by judicial case management and costs discretion.
Cherchant constammenl à moderniser et améliorer la pièce de procédure en matière civile. les Alberta Rules of Court furent anendies en 1999. Des dossiers d'affidavits son automatiquemem requis dans une periode de remps donnée et la non-conformité est passible du droit quasi automatique de doubler les couits. Cet article retrace la genèse de ces nouvelles règles, particulières d̀ I'Alberfa. puis détermine plusieurs préoccupations el les analyse d'un oell critique. Les auteurs concluent qu en pratigue. ces anendements qui remontent à cinq ans. généralement ne font pas accélérer la procédure, ni réduire les frais des plaideurs ou du public, ni ne facilite le reglement sur le fond d'im differend et n'améliore pas la perception que le public a de l'administration de la justice civile. En fait. elles pourraient avoir l'effet contraire de l'objectif qui etait d'encourager le règlement et de faire preuve de prudence en ajant recours aux tribunaux. Les auteurs suggèrent que le projet de règles de procédure du Alberia Law Reform Instimte devrail proposer lamnulation de ces amendements et revenir au moddle demande. renforcs par la gestion de causes judiciaires ef discréfion en matière de coits.

\section{TABL.E OF CONTENTS}

I. INTRODUCTION ............................. 954

II. USES AND ABUSES OF DISCOVERY IN CIVIL LITIGATION .......... 955

11I. Pre-1999 Rules ON DOCUMENT Discovery IN ALBERTA . . . . . . . 957

IV. MOMEnTum for Change: Canadian Bar AsSOCiation

TASK FORCE ON SYSTEMS Ol: CIVIL. JUSTICE . . . . . . . . . . . . . 959

A. CANADIAN Bar ASSOCIATION FORMED ITS TASK FORCl:

ON SYSTEMS OF CIVIL JUSTICE . . . . . . . . . . . . . . . . . . . . . . 959

V. THE 1999 ALBERTA REFORMS TO THE DOCUMENT

DISCOVERY RULES .......................... 961

A. CANADIAN FORUM FOR CIVIL JUSTICE $\ldots \ldots \ldots \ldots \ldots \ldots \ldots, 961$

B. 1999 AMENDMENTS TO THE RULES ............... 962

C. ALBERTA LAW REFORM INSTITUTE "RULES OF

Court Project" .............................. 965

VI. THE NEW AI.BERTA RUI.ES ON EXCHANGing AFFidAVITS

OF RECORDS . . . . . . . . . . . . . . 966

-. Haskayne School of Business, University of Calgary, Calgary, Alberta.

- B.A., University of Calgary, Calgary, Alberta. 
VII. NEW Alberta RULES COMPARED TO OTHER

CANADIAN JURISDICTIONS . . . . . . . . . . . . . . . . . . . 968

A. The Name AND NATURE OF THE INSTRUMENT

of Production . . . . . . . . . . . . . . . . . . . 968

B. Mandatory versus On Demand Production ........... 968

C. SANCTIONS fOR NON-COMPLIANCE: ................969

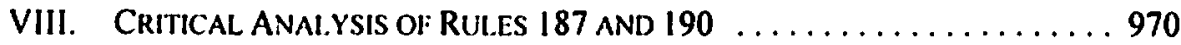

A. ARgUMENTS AgAINST RULE $187 \ldots \ldots \ldots \ldots \ldots \ldots . \ldots 91$

B. ARGUMENTS AGAINST RULE $190 \ldots \ldots \ldots \ldots \ldots \ldots \ldots . \ldots 975$

IX. CONCLUSION ............................. 992

The Rules pertaining to the late filing of affidavit of records are described ... as penal... I can at least say they are draconian.'

[T]his entire issuc has been a ncedless waste of evenone's valuable resources and time. ${ }^{2}$

This is all much ado about little... The matter got worser and worser... This matter has gotten out of hand. ${ }^{3}$

\section{INTRODUCTION}

Civil practice and procedure in the Alberta Court of Queen's Bench and the Alberta Court of Appeal are governed by the Alberta Rules of Court (Rules). The Provincial Court of Alberta, principally governed by the Provincial Cours Act, ${ }^{4}$ has discretion to "apply ... and modify the Alberta Rules of Court as needed," but only where "necessary to ensure an expeditious and inexpensive resolution of a matter."

These rules have undergone numerous ad hoc amendments over the years. The last comprehensive revision was in $1968 . .^{6}$ In the intervening time, many of the same concerns about the length of delays, cost and complexity of proceedings have been expressed by the legal and lay communities. Reports across the country, and in the United Kingdom, of

(irzybowski v. Fleming. 2001 ABQB 259 at para. 4 [Cirzybowski].

Sustrik v. Alberla AG-Bag Ldd. (200I), 301 A.R. 192 at para. 22 (Q.B.)

Sustrik v. Alberla AG-Bag lidd. $2001 \mathrm{ABQB} 395$ at paras. 8, 10, 12.

Provincial Court Act, R.S.A. 2000, c. P-3I. There is no procedure for discovery in the Civil Division of the Provincial Court of Alberta, despite a generous nonetary jurisdiction.

Ibid., s. 8(2). Few Civil Division cases could justify invoking the discovery stage on the grounds of expedition and cost saving.

Alta. Reg. 390/68. 
malaise in civil justice documented these concerns. ${ }^{7}$ This led Alberta to reconsider and amend its rules of civil procedure in late 1999.

This article critically analyzes the new rules that impose mandatory double costs on someone who does not file an affidavit of records within 90 days of service of the statement of defence.

\section{USES AND ABIISES OF DiSCOVERY IN Civil Litigation}

The discovery of documentary and viva voce evidence is the second stage of five in the common law civil process in superior court. It takes place after pleadings and before trial. ${ }^{10}$ While settlements may take place before trial and therefore without discovery, most counsel will be reluctant to enter into settlement negotiations until completion of the discovery stage. Issue-defining and notice-giving is not complete after the exchange of pleadings. " Pleadings themselves "do not give a very full picture of the claims or defences that will actually be presented at trial, and hardly provide sufficient information to allow for adequate trial preparation or meaningful settlement discussions."12 Accordingly, conventional wisdom affirms discovery to reduce both the time and cost of lawsuits, compared to what would come to pass without it. ${ }^{13}$

The Canadian Bar Association's (CBA) Report of theTask Force Report on Systems of Civil Justice summarized "the objectives of discovery are to learn the case to be met; to obtain admissions (thereby reducing trial time); and, to avoid ambush."14 Obtaining and putting the opposing party's admissions on the record at an early stage is thought to save time

Ontario Civil Justice Review. C'wl Justice Review: First Report (Toronto: Ontario Civil Justice Review, 1995); Ontario Civil Justice Review, Civil Justice Review: Supplemental and Final Report (Toronto: Ontario Civil Justice Review, 1996); Lord H.S. Woolf, Access to Justice: Imterim Report to the Lord Chancellor on the Civil Justice System in England and Wales (London: Lord Chancellor's Department, 1995); Lord H.S. Woolf, Access 10 Justice: Final Report to the Lord Chancellor on the Civil Justice System in England and Wales (London: HMSO. 1996); and Canadian Bar Association. Task Force on Systems of Civil Justice, Report of the Task force on Sjstems of Civil Jistice (Ottawa: Canadian Bar Association, 1996).

" Alberia Law Reform Institutc. Rules of Court Project: Document Discoven and Examination for Discovery: Consultation. Memorandum No. 12.2 (Edmonton: Alberta Law Reform Institute. 2002) at ix [Consullation .Memorandum No. 12.2].

" The object of the production of Jocuments in actions is to enable either party to discover the existence and acquire aknowledge of the contents of the deeds and writings relevant to the case" in the possession or control of the other party (Darling v. Darling (1883), 10 P.R. I at I (Ont. H.C.J.)). "IW]hile memories are fresher" according to Clare E. Chonte, Discovery in Canada (Toronto: The Carswell Company Limited. 1977) at 16. The other uwo stages are appeal and entorcement of the judgment.

" Garny D. Walson et al. The Civil Lirigarion Process: Cases and Materials, Sth ed. (loronto: Emond Montgomery Publications L.dd., 1999) at 775-76. The authors also assert that document discovery properly precedes oral examinations so that counsel can ask the best questions. In oral discovery, the process of document production often continues as questions relating to the documents and the facts disclosed from the documents will be explored in greater depth. Ibid. at 776.

13. See generally, Kevin P. Feehan \& A. Leah Lis, "Re-Discovering Discovery: A Briel Review of the History and Purpose of Examinations for Discovery" in 37th Anmeal Banfl Refresher Course on Civil Litigation (Edmonton: Legal Education Society of Alberta. 2004). 
overall in the litigation. Counsel get not only a sense of the case to be met, but also a sense of the credibility of the other side. ${ }^{\text {is }}$ The use of prior inconsistent statements is another collateral check on credibility.

Document discovery is argued to be integral to resolution because, inter alia, "[c]arefully prepared affidavits of documents lay a good foundation for examination for discovery. They save a good deal of wasted time during examination for discovery by informing the parties beforehand, reducing undertakings, removing the need for many routine questions ... and removing the need to mark exhibits."16

Discovery burnishes the civil process with relevance, efficacy and faimess ${ }^{17}$ because costs are saved by promoting settlement or reducing the issues in dispute and limiting the scope and length of the trial. ${ }^{18}$ The issues in dispute are focused and weaknesses revealed in some allegations, which facilitates presentation of evidence at trial. ${ }^{19}$ It may prevent a party being taken by surprise at trial and enable the dispute to be determined upon its merits rather than "on mere tactics." ${ }^{20}$ Moreover, most authors agree that discovery enables the parties to assess, at an early stage, the strengths and weaknesses of their case and this can lead to early pre-trial settlement. ${ }^{21}$ Since an intended benefit of discovery is to eliminate surprise and to promote settlement or adjudication in the light of relevant facts rather than in darkness, Levine adds that discovery is intended "to blunt some of the rough edges of the adversary system," and to serve as "an antidote to the "sporting theory" of justice"22 or what is referred to as "trial by ambush." 23 If discovery is not a "sport," it may be an "art."24 Claims and defences can be tested early and trials precluded. ${ }^{25}$ If there is trial, parties can assist the court (and therefore their own private cause and the public interest) by sharper and more efficient presentation of their evidence, which focuses the judge's understanding of the issues.

Consultation Memorandum No. 12.2, supra notc 8 at 1.

W.A. Stevenson \& J.E. Côtc, Alberta Civil Procedure Handbook 1998 (Edmonton: Juriliber, 1998) at 121 .

"["] o render the judicial process more accurate and fair": David W. Louisell \& Barry M. Wally, Modern California Discovery, 2d cd. (San Francisco: Bancroft-Whitney, 1972) at 782.

See generally, S.D. Simpson, D.L. Bailey \& E.K. Evans, Discovery and Imerrogatories (Toronto: Butterworths \& Co. L.d.., 1984) at 1-2. They assen "the main function of discovery is to provide the parties to civil litigation with relevant documents before trial to assist them in preparing their case for trial or in determining whether or not to settle before trial."

Choate, supra note 10 at 5; Louisell \& Wally, supra note 17 at 783-84.

Simpson, Bailey \& Evans, supra note 18 at 2.

Ibid.; see also, Choate, supra note 10; Julius Byron Levine, Discovery: A Comparison behween English/ and American Civil Discovery Law with Reform Proposals (Oxford: Clarendon, 1982) at 1; Wigmore on Evidence, rev. ed. by James HI. Chadbourn (Boston: Little, Brown \& Company, 1979) at Book I. Part II, Title III at 925; Bank of B.C. v. Trapp (1900), 7 B.C.R 354 (B.C.S.C.); L ouisell \& Wally, supra note 17 at 783-84; and U.K.. H.L., Parhamentary Debales, 20 ser., vol. 188 (7 February 1828), state: "[W]hatever brings the parties to their sense as soon as possible, especially by giving each a clear view of his chances of success or failure and, above all things, making him well acquainted with his adversary's case at the carliest possible moment, will always be for the interest of justice."

Levine, ibid. at 2.

Gordon D. Cudmore, Choate on Discovery, 2d ed., looseleaf (Toronto: Carswell, 1993) at 1-2.

Sec e.g. Robert B. White, The Art of Discovery (Ontario: Canada Law Book, 1990).

"Developments in the Law - Discovery," Nole (1961) 74 Harv. L. R. 940 at 944-46. 
On the other hand, the promise of discovery can be abused in the adversarial process by miss or mischief. In 1998 Stevenson and Côté described the document discovery rules as "important, yet often neglected or badly handled."26 As most litigators would attest, the discovery process is not always employed for the wholesome public purposes described above. There is, in practice, often abuse of discovery and comuption of its ideals. Primarily conducted extra-judicially, discovery is an exercise premised on the good faith of adversarial parties and their counsel who are sworn to zealous advocacy.

While discovery can, and should, be used to find truth, "it must not be made an instrument of torture"27 or an "opportunity to multiply irrelevant and impertinent questions." ${ }^{28}$ It might "also be productive of delay" and encroach upon personal and professional privileges. ${ }^{29}$ Extensive discovery, with harassment and expense, might induce a party "to accept an otherwise injudicious settlement." ${ }^{30}$ Slavish use of discovery can swamp the parties with masses of material tending to delay the proceedings and fog the real issues. ${ }^{31}$ Discovery, therefore, can be turned into a bully pulpit that may only be dealt with by numerous costly and time-consuming interlocutory applications. To the parties, discovery is one of the most expensive stages of civil proceedings and an enticing opportunity, albeit an improper one, to intimidate and discipline the other side with costs and obfuscation. As such, the right to discovery can exacerbate the concerns that it is intended to alleviate. It may impose the burdens of costs and inconvenience that may be disproportionate to its value or to the significance of the litigation. ${ }^{32}$

\section{Pre-1999 Rullfs ON DoCUment Discovery in Al,Berta}

Up to 2000, r. 186(2) of the Alberia Rules of Court stated:

Al any time after the close of pleadings any party to a cause or matter may by notice in writing require any
other party to the cause or matter adverse in interest, to discover by affidavit the documents which are or which
have been in his possession or power relating to all matters or questions in the cause or matter, and the party
so required shall within 10 days after receipt of the demand discover by affidavit the documents requested.

The rule was poorly drafted. The party doing the "discovering" is actually the party with the documents, revealing them to the "notifying" party. Moreover, it is facially ambiguous in the "within 10 days ... discover by affidavit" terminology. Did it mean that the affidavit had to

Supra note 16 at 121 . Curiously, the authors say exactly the same of the new rules (W.A. Stevenson \& J.E. Cỏté. Alberia Civil Procedure Handbook 2002 (Edmonton: Juriliber. 2002) at 143 [Stevenson \& Côté, 2002].

" Choate, supra note 10 at 16.

2x lbid. A Committec of the Alberta Rules of Court Project referred to this in terms of another sporting metaphor i.e. the "Jishing expedition"(Consultation Memorandum No. 12.2, supra note 8 at 1-2).

2" Choate, ibid. at 24.

"Ibid

" Simpson, Bailey \& Evans, supra note 18 at 2.

: Choate, supra note 10 at 7.

"In Alberta, discovery is governed by the Judicature Act, R.S.A. 2000, c. J-2 and the Alberta Rules of Court, Alta. Reg. 390/68, rr. 186-217, as amended by Alta. Reg. 172/99. 
be filed only or filed and served within the ten day time period? $?^{34}$ The implication was that the affidavit was required to be drafted, filed and served within the ten day period because the notified party would not have effectively "discover[ed] by affidavit" until it had realized service. Reading beyond the rules about very long trial actions, assignors of choses in action and corporate officers, $r$. 189(1) completes the obligation that "the affidavit shall be filed and a copy shall be served within the time limited for filing upon the party requiring it."

The duty was enforced by an array of effective penalties. A "party not producing any document in compliance with a demand," which ostensibly included an affidavit of documents, or who omitted to properly mention a document in the affidavit of documents, was prima facie precluded from later using that document in evidence. ${ }^{35}$ Moreover, on motion, the non-compliant party could also be cited in civil contempt ${ }^{36}$ imprisoned for up to two years $s^{37}$ and fined. ${ }^{38}$ The party in default of $r$. 186(2) could further have one's pleadings struck out ${ }^{39}$ and an adverse judgment entered. ${ }^{50}$

Despite these strict sanctions for non-compliance with r. 186(2), there are few reported cases in Alberta where these penalties were imposed. Counsel widely accepted that ten days was frequently not enough notice for a party to prepare, file and serve an affidavit of documents, particularly in complicated cases. Therefore, they did not insist on specified formal timeliness in the same way they relaxed compliance for other limitation periods.

For example, 15 days is widely seen as too short a period in which to prepare and deliver ${ }^{41}$ a statement of defence or demand of notice. ${ }^{42}$ In cases where both parties are represented by reputable counsel, the professional courtesy is invariably extended of extending time and agreeing not to note the defendant in default without reasonable further notice. An informal professional convention has become the practice between counsel to enlarge time in lieu of insistence upon technical compliance with the strict timelines prescribed in the Rules. ${ }^{.3}$ The professional courtesy to relax this limitation period arises also out of the realization that most steps and defaults in civil procedure are reversible ${ }^{44}$ and as such, ironically, insistence on

1. Other pre-1999 Part 13 rules were more precise on this point. For example. rr. 196 and 197, referred to service of the notice of production, but not to the affidavit itself. Rule $190(1)$ speaks of service of the aftidavit and $t$. $190(2)$ creates a limitation period of " 30 days after service of an affidavit of documents." See also r. $190(4)$.

" "[U]unless he salisfies the court that he had some sufficient cause for the omission or nonproduction" (r. 195(1)). See also r. 704(1)(d)(iv), a broader proluibition on evidence.

*. Alberta Rules of Conrt, supra note 33, r. 703(b). Note all rules cited, unless otherwise specified, refer to the cursent Alberia Rules of Court.

Rule 704( 1 )(b).

Rule $704(1)(c)$.

Rule 704(I)(d)(i).

Rule $704(\mathrm{I})(\mathrm{d})(\mathrm{iii})$.

For pleadings, unlike for affidavits of production, the operative predicale is "delivery:" which has long been explicitly defined as "filing and service" (r. 84).

Rule 85(1)(b).

This collegial practice within an adversarial context is not observed without exception. It is consistent with the call to greater civility in the profession, the value of reputation and the practical wisdom of "live by the sword, die by the sword."

14 The defendant may apply to set aside the default judgment (rr. 31. i(c), 158, 257). 
strict performance with time limitations likely increases costs and delays in the process. ". One will find many more procedural disputes about the content of affidavits, completeness, privilege, "further and better" and inspection, than about whether the affidavit was filed and served on time.

\section{Momentum for Ciange: Canadian Bar Association TASK FORCF, ON SYSTEMS OF CIVII. JUSTICE}

Even after case management, judicial dispute resolution and long trial procedures were introduced across Canada, a consensus continued to emerge that the discovery of documents phase was too slow and sketchy. It was identified as one of the primary sources and causes for the delay and high cost of getting to civil judgment.

\section{A. Canadian BAR ASSOCiation fORMFd its TASK FORCE ON Syste.MS OF Civil. JISTIC.}

A decade ago, in 1995, the CBA formed its Task Force on Systems of Civil Justice. The Task Force's mandate was "to enquire into the state of the civil justice system [on a national basis] and develop strategies and mechanisms to assist in the continued modernization of the system so that it is better able to meet the current and future needs of Canadians." ${ }^{977}$

Its surveys of lawyers and the general public revealed three areas most in need of improvement: the speed and the affordability of dispute resolution in the civil courts and public understanding of the work of the courts and the judicial system as a whole. ${ }^{48}$. The 84page Task Force report, tabled at the CBA annual meeting in August 1996, featured 53 recommendations to modernize civil justice systems across Canada. ${ }^{40}$

While the Task Force report considered most aspects of civil dispute resolution, it concentrated upon what it viewed as a primary concern: the sluggishness of litigation. ${ }^{30}$ For various reasons, lawyers often have no real incentive to proceed expeditiously through lawsuits. The negative consequences of delay (borne by clients, the system and taxpayers)": are as numerous as they are serious. The Task Force's list included "ligher costs for clients; erosion and sometimes loss of evidence resulting from the passage of time and the fading of memories; stress and frustration for clients, lawyers, judges, and court administrators; in

The Rules have not been formally reconciled with the practice, despite the specific objective of the Alberta Law Reform Institute to "updat[e] the rules to reflect modern practices" (supra note 8 at $\mathbf{x}$ ). Judge Allan Fradsham highlighted the impontance of ensuring that all documents are mentioned in an affidavit. He stated, "This rule is most important. It makes non-compliance with the rules regarding production of documents very risky. Therefore, particular athention should be paid when drufting affidavits of documents" (Altan $A$. Fradsham, Alberta Rites of Cotri dmotated 1998 (Scarborough. Ont.: Carswell, 1997) at 287 (emplasis added)).

Canadian Bar Association, supra note 7 at 3 . Note the repon is also available online: Canadian Bar Association < wnww.cba.org/CBA/cba_reports/pdf/systemscivil_tlireport.pdt?.

lbid. at 12.

The recommendations were adopted by the CBA National Council at its mid-winter meeting in February 1997.

Canadian Bar Association. supra note 7 at 13.

lbid. at 13 . 
some circumstances, erosion and loss of legal remedies because of the passage of time; increased likelihood of professional negligence; and decreased confidence in the administration of civil justice." 32

The Task Force pointed out that delay increases litigation costs. ${ }^{53}$ Moreover, these higher costs are not imposed upon the litigants alone: "[f]or society as a whole, the components include expenditures for court facilities, legal assistance programs, support staff (including court administrators), and judges." $\$ 4$

According to the Task Force, "[o]ne of the most significant difficulties is that the time requirements imposed by existing rules of procedure are often honoured more in the breach than in the observance." 55 This came as no surprise to civil litigators who frequently and deliberately invoke delay for various tactical reasons. Accordingly, "it was suggested to the Task Force by many that stricter enforcement by the courts and lawyers of existing procedural rules would go a long way to reducing delays." ${ }^{66}$

The Task Force noted the "nearly universal dissatisfaction"s7 with discovery rules across Canada. It identified the discovery phase as the most obvious source of delays and correspondingly unnecessary costs. ${ }^{58}$ Discovery delay was primarily attributed to the "complexity and number of discoveries and scheduling problems in the [oral] discovery process." ${ }^{\circ 9}$ No delay was attributed to the timely exchange of production affidavits.

A solution lay in the concept of "time standards ... to set time limits for various stages in an action." 100 The Task Force envisioned these standards to "be incorporated in the rules of the court, enforced by the court and subject to sanctions for non-compliance; to set overall determination time(s) as targets for all cases or specific classes of cases but not as enforceable provisions applicable to individual cases; and to set a limit on the overall time that a case can remain on the court docket."

The specific procedural reforms recommended by the Task Force to expedite and simplify discovery and pre-trial procedures focused upon the following: the use of "will-say" statements; ".limit[ing] the scope and number of oral examinations for discovery and the time available for discovery",; "assist[ing] parties in scheduling discoveries and in resolving discovery disputes"; ${ }^{64}$ early disclosure and the exchange of expert reports; ${ }^{.5}$ limiting appeals

\author{
Ibid. at 15 . \\ Ibid. at 13 \\ Ibid. at 15. \\ Ibid. at 13 . \\ Ibid. \\ Ibid. at 43. \\ Ibid. at 15 . \\ Ibid. at 43. \\ lbid. at 38 . \\ lbid. \\ Jbid., Recommendation 15 at 43. \\ Jbid., Recommendation I6(a) at 43. \\ Jbid., Recommendation 16(b) at 43. \\ Jbid., Recommendation I7(a) and (b) at 44
}


from some interlocutory proceedings; immediate cost awards in motions and strict financial sanctions for cases of abuse, ${ }^{.66}$ and summary trial procedures. ${ }^{67}$

Other specific recommendations unrelated to timeliness, and beyond case management, ${ }^{68}$ included: "eliminating oral discovery in cases to be dealt with through expedited and simplified proceedings"; "limiting the number of examinations"; "restricting the scope of discovery" and narrowing the standard of relevance, sanctioning duplicative discovery; mandating discovery conferences among counsel and judges; and "creating more effective processes to resolve conflicts as they arise in the discovery process, through case management and teleconferencing or "hotline' arrangements with chambers judges." 69

It is important to note here that the Task Force, while it advocated development of "system[s] of incentives and sanctions to encourage settlement and prudent use of court time," ${ }^{10}$ did not propose a procedure requiring an automatically time limited exchange of production affidavits in every civil action, enforced by an essentially mandatory sanction in double costs payable forthwith.

The mandatory "incentives and sanctions" procedure adopted by Alberta in 1999 in practice does not serve to expedite proceedings or reduce overall costs. The new rules do little to advance the progress of lawsuits. The award of double costs on grounds unrelated to merits arguably hinders resolution of the matters in dispute. When the double costs sanction is invoked, it may actually discourage "settlement and prudent use of court time."

\section{THE 1999 ALBERTA REFORMS TO TIE DOCUMENT DISCOVERY RULES}

The CBA Task Force recommendations were greeted and acted upon in Alberta more than anywhere else in Canada. This reception was manifested in several forms.

\section{A. Canadian forum for Civil. Justice}

The CBA Task Force identified weaknesses in civil justice information gathering and sharing in Canada and recommended creating "an independent national organization on civil justice reform" " with six specific purposes. ${ }^{72}$ Under this recommendation, the CBA and the

is Ibid. Recommendation 19 at 45.

(5) Ibid, Recommendation 20at 45.

in "Under a caseflow management system where there is a systemic approach to managing cases. the court monitors progress throughout the process and deadlines are imposed for completion of procedures, such as motions, discoveries and setılement conferences" (Doris 1 . Wilson, "Managing Litigatıon in Canada" News and View's on Civil Jistice Reform 5 (Fall 2002) 4, online: Canadian Forum on Civil .luslice <ivww.cfcj-fcjc.org/issue_5/n5-dwilson.htm>l.

(.) Canadian Bar Association, supra nole 7 at 43

2. $\quad$ lbid. Recommendation 21 (a) at 46.

" Ibid. Recommendation 52 at 78.

1: Recommendation 52 envisioned a body "for the purposes of (a) collecting in a syslematic way information relating to the system for administering civil justice; (b) carrying out in-deptls research on matters affecting the operation of the civil justice system: (c) promoting the sharing of information about the use of best practices; (d) tunclioning as a clearinghouse and iibrary of inliumaliun liur the: benefit of all persons in Canada concerned with civil justice reform. (c) developing liationn with similitr 
Faculty of Law at the University of Alberta jointly established the Canadian Forum on Civil Justice (the Forum) in May $1998 .^{73}$

\section{B. 1999 AMENDMENTS TO THE RULES}

The object here is to encourage a timely production of documents but to eliminate the concept of "tertiary" relevance which results in cndless production of documents only marginally relevant. ${ }^{\text {"4 }}$

At approximately the same time the Forum was launched, and largely as a response to some of the CBA Task Force recommendations, amendments to Part 13 of the Rules were recommended by the Rules of Court Committee ${ }^{75}$ to the Minister of Justice. The Rules of Court Committee derives its authority from of the Court of Queen's Bench $\mathrm{Act}^{76}$ and occasionally from the Court of Appeal Act. ${ }^{77}$ The Committee, which makes recommendations about changes to the Alberta Rules of Court to the Minister of Justice, is composed of the Chiefs of each of the three Alberta courts (or their respective designates), two Law Society of Alberta appointees and a Minister of Justice appointee. Specifically, the Discovery Reform Subcommittee was charged to generate reform proposals on document discovery:

\section{New Set of Rules?}

There is general consensus that the existing Rules of Court may be in need of a comprehensive overhaul. There have been so many amendments and changes that some practitioners find the rules unwieldy, and at limes confusing. A subcommittee consisting of Mr. Justice Coté, Eric Macklin and Geofr Ho has been established to pursue this. ${ }^{78}$

It is difficult to verify the foundations of this "general consensus" in Alberta or precisely which rules "some practitioners" found to be "unwjeldy, and at times confusing." If it justified "a comprehensive overhaul," such was not on the drawing board on this first round. Within several months, the composition of the Subcommittee itself changed completely.

By April 1998, the Subcommittee focused on delivery of the affidavit of production. It informed the profession of the broad outlines of upcoming reforms, and input was solicited. The Law Society's Benchers' Advisory records:

The last meeting of the Rules of Court Committee was held February 18th, 1998. A number of substantive amendments to the rules are being discussed and your comments on each of the following issues would be appreciated.

organizations in other countries to foster exchanges of information across national borders; and (n) taking a leadership role on information provision concerning civil justice reform initiatives and developing effective means of exchanging this information" (ibid.).

Sec online: Canadian Forum on Civil Justice <iwww.cfcj-fcjc.org>.

Alan D. Macieod \& Eric Macklin, "Rules of Coun Update" (August 1998) 56 Benchers' Advisory 4. Justice Jean Cote initially served as the committee chair.

R.S.A. 2000 , c. C.31, s. $25(1)$.

R.S.A. 2000 , c. C-30, s. 16.

Alan D. Macleod \& Eric Macklin, "Rules Committee Update" (February 1998) 53 Benchers' Advisory 8. 


\section{Discovery Reform}

The Discovery Reform Subcommittee chaired by Mr. Justice Belzil has pul lorward its report outlining substantive changes to the Rules of Cour dealing with the discovery process. The proposed rule amendments reflect the following changes in approach to both discovery of documents and examinations for discovery:

\section{Document Discovery}

a) The elimination of Rule 186(2) which requires a party to discover by aflidavit the decuments in its possession within 10 days of receiving a demand to do so. The proposed amendments reflect the following:

i) every party to an action is required to file an Aflidavit on Production within 90 days of the service of a Statement of Defence;

ii) a party who has not filed an Affidavit on Production shall not be entilled to examine for discovery:

iii) no party shall be entitled to recover Schedule C costs unless the Affidavit on Production was filed in a timely fashion:

iv) an exception or exemption from the requirements in (i) or (ii) above must be granted by a judge on application by the party secking the exception or exemption.

It is to be recognized also that the procedural amendments may be workable for the majorily of actions but exceptions must be built in for complex actions or actions necessarily involving a large volume of documents As you can see, there are subsiantial changes being proposed and your comments are welcome. Please address any comments you may have to... 79

The new four-person bench-bar Subcommittee continued to deliberate, and communicated with the profession a few months later in the Benchers 'Advisory:

\section{Discovery Reform}

This discussion [about discovery reform] occupied much of the meeting. A committec, consisting of Justice Belzil (Chair), Justice Brooker, Rob Graesser, Q.C., and Lou Cusano, has been working diligently on recommendations to expedite lise discovery process, both with respect lo documents and oral discovery. You will recall that this was the subject of our last report, and the recommendations have been distributed previously. While the committee favoured most of the recommendations, the matter has gone back to the committec for some redrafting in light of your comments. We are hopeful that we will be able to agree on a concrete proposal at our next meeting so that the new provisions can take effect sometime next spring. The object here is to encourage a timely production of documents but to eliminate the concepn of "fertiary" relevance which results in endless production of documents only marginally relevam. Counsil will also be discouraged from examining every employee and former employee who may conceivably have any knowledge touching the matters in question. ${ }^{80}$

A goal in the reforms was "to encourage a timely production of documents," but it was not explained how the existing rules were inadequate to that task. One was even more challenged to envisage how the other stated goal, "to eliminate the concept of 'tertiary' relevance which results in endless production of documents only marginally relevant." was significantly advanced by the proposals. 
A collateral concern that informed the Subcommittee was the decline of civility between lawyers. In the Law Society's 1998 Annual Report, the Chair wrote:

\begin{abstract}
The [Civil Practice Advisory] committee had considerable concern during 1998 with what appears to be an increasing incidence of acrimonious dealing and a lack of civility between practitioners. Anecdotedly there appears to be ever increasing instances of confrontation and unprofessional conduct between members of the Law Society, and reports from the practice advisor indicate that there is indeed a growing trend in this regard. The committee has prepared a number of articles for the Benchers' Advisory discussing the importance of civility and professionalism in practice. in a recent anticle. Barry Vogel asked how lawyers can expect to be regarded with respect by society when they too often treat their fellow lawyers in a rude and unprofessional manner. It is hoped that these articles will help promote awareness of the problem and discussion on how this trend can be reversed. ${ }^{81}$
\end{abstract}

By June 1999, the adoption of these new rules ${ }^{82}$ was complete:

The Rules of Court Committec met on April 121h, 1999. Matters discussed include the following:

Discovery Rules 186-216.1

While previous updates outlined clanges proposed to the discovery process hy the committec chaired by Mr. Justice Belzil, implementation of change had been delayed to ensure that the changes desired by both Justice Belzil's committee and the Rules of Court Committee would be accomplished by the wording suggested. ${ }^{83}$

The Law Society of Alberta's 1999 Anmual Report referred to "themes of reform advanced, proposing changes to the scene of civil litigation," including the need for class action legislation, new Rules of Court on taxable costs in contingency fee agreements and in Schedule C, "[ $[$ ] he need for more restrictive Rules for pre-trial discovery processes, a matter which produced new and controversial Rules of Courl effective November 1, 1999."84 References were made generally to the CBA Task Force and the Woolf Report in the United Kingdom in the interests of access to cost-effective and timely civil justice. ${ }^{85}$ According to Stevenson and Côté, the Alberta amendments were "designed to cut down the scope of relevance ... make discovery of records automatic, increase the penalties for non-compliance. and make the terminology a little less confusing."

Anthony L. Friend. "The Civil Praclice Advisory" in Law Society of Alberta. Ammal Report 1998 (Calgary: Law Sucicty of Alberta, 1998) 13 at 13-14.

We refer to these as the "1999 amendments," but they were phased in through 2001, by three separate Alberta regulations (Alta. Reg. 172/99. Alta. Reg. 68/00, Alta. Reg. 109/01).

Eiric Macklin \& Alan Macleod, "Rules of Court Update" (June 1999) 60 Benchers" Advisory 7.

Everelt L. Bunnell, "The Civil Practice Advisory" in Lanr Socieg' of Alberta. Anmual Report. 1999 (Calgary, Law Society of Alberta, 1999) 12 at 12.

It was stated that " $[t]$ he machinery of civil justice and access thereto on a cost-effective and timcly basis are topics of the Woolf Report in the United Kingdom and are the subject of recommendations tron the Alberta Implementation Committee of the CBA Task Force on Civil lustice Reform" (ibid.). Supra note 26 at 137. 


\section{Alberta law Reform InStitute "Rules of Colikt Projf.ct"}

Alberta took the lead in reforming its civil procedure in a third respect. The Alberta Law Reform Institute (ALRI) in 2001 established its Rules of Court Project (the Project). The Project formed several committees to study and solicit input on reforms with the objective of maximizing the Rules' (1) clarity, (2) useability, (3) effectiveness and (4) advancement of the justice system's goals. ${ }^{87}$ With respect to the third objective, the Project sought to "updat[e] the rules to reflect modern practices" and make "pragmatic reforms to enhance the courts' process of justice delivery." ${ }^{88}$ The fourth objective of the reform effort, to "maximize the rules' advancement of justice system objectives," envisions "pragmatic reforms to advance justice system objectives for civil procedure such as fairness, accessibility, timeliness and cost effectiveness." ${ }^{89}$

The ALRI noted that the discovery process required "a great deal of attention" and formed the Discovery and Evidence Committee ("the Committee") to consider reform of the discovery rules. ${ }^{\text {. }}$ The work of the Rules of Court Project is ongoing. "This "major review" aims to recommend a "new set of rules" by the end of 2004. ${ }^{12}$ One might have expected the Project to exclude the 1999 discovery amendments from its review, but it is also reconsidering these recent amendments. ${ }^{93}$ We believe that the Project's recommendations ${ }^{94}$ with regard to the 1999 amendments are too modest, and we argue that rr. 187 and 190 to 190.1 should be repealed and the former r. 186(2) reinstated.

"Consultation Memorandun No. 12.2. supra note 8 at $\mathrm{x}$

nu Ibid.

ibid. at xi.

(n) Ibid. at xvi.

"1 The Project has circulated ten consultation memoranda between October 2002 and July 2003. Only two of these, Document Discovery and Examination for Discovery (12.2) (ibid.), and Alberta Law Reform Institute, Rules of Courl Project: Discovery and Evidence Issues: Commission Evidence. Admissions. Pierringer Agreements and Innovative Procedures, Consultation Memorandum No. 12.7 (Edmonton): Alberta Law Reform Institute, 2003) [Consultation Memorandum No. 12.7] are referred to in this article. Eight other papers and reports have been published. All documents are available online: Alterta Law Reform Institute <www.law.ualberta. ca/alri/rules_table.htm|>.

": Memorandum No. 12.7, ibid at xi.

"The following was stated in both Consultation Memorandums circulated by the Alberta Law Reform Institute: "Reforms have been adopted in Alberta and elsewhere 10 address these issues. In Alberta, somic of these new procedures have been included in amendments to the rules... The Rules Project will review and assess reform meisures that have been adopted" (sipra note 8 at ix-x: sipro note 91 al Nixii).

य Consultation Memorandum No. 12.2, supra note 8. These Project recommendations are discussed below: 


\section{THE NEW ALBERTA RULES ON \\ EXCHANGING AFFIDAVITS OF RECORDS}

Many rules were changed as a result of the amendments that began in 1999." Some of them had to do with definition of "record," or record is relevant and material," of these rules represent significant substantive changes and they have already attracted much judicial disposition. This article is not interested in those changes to the Rules. We will focus only on the mandatory requirement to exchange an affidavit of records within 90 days of service of the statement of defence under the penalty of double costs. These new rules are set out below. ${ }^{100}$

\section{Aflidavit of records must be filed}

187(1) Every party to proceedings must, in accordance with this Rule. file and serve on all olher parties an affidavit of records, unless the Court grants an order under Rule 188.1 permilting a late filing or service of the affidavit. $^{101}$

187(2) $A$ third party and a party served under Rule 69 who has filed a stalement of defence must, within 90 days of that filing. file and serve on all other parties an affidavit of records, unless the Court grants an order under Rule 188.1 pernitting a later fïling of the affidavit.

$187(4)$ Rule 548 does not apply to a lime limit specified in this Rule. ${ }^{102}$

$187(5)$ The time limit for filing and serving an affidavit of records in divorec. parentage and maintenance. mutrimonial properly and domestic relations actions is

(a) 90 days atter a written notice is served by a party on the other party or parties requiring that this Rule be complied with.

(b) in the case of the party serving the notice, within 90 days after service of that notice. or service of the first notice if more than one party is served, or

(c) if no written notice is served under clause (a), before the later of

(i) the filing of a Certificate of Readiness, or

(ii) 90 days beforc the trial date. ${ }^{103}$

Other recent procedural changes make litigation more convenient and efficient, including taking advantage of widely available technology: service of legal documents by telecopier (r. 16.1). soft copies of computer generated documents (r. 5.11), applications by conference telephone (r. $385.1(1)$ ). document exchange (r. 26), strcamlined procedure ( $\mathrm{Par} 48)$ and the requirement to note in the original pleading whether the trial is likely to take longer than the 25 days (r. 87). which defines (lie "very long trial action" (r. 5(1)(u)). Alta. Reg. 172/99, s. 3, which annended r. 186.

Jbid. s. 3, which amended r. 187.1.

Ibid., s. 3. which anended r. 186.1.

libid, s. 3, which amended r. 188.

Several other Canadian jurisdictions adopted "simplified procedings" that feature time standards similar to Part 48 (Streanlined Procedure) of the Alberia Rules of Courts. However, Alberta is alone in adopting a strict time standards regime for delivery of affidavils ol records.

Alta. Reg. 68/2000. s. 3.

Alta. Reg. $172 / 99$, s. 3.

Alta. Rcg. 109/200I. s. 4 
187(6) The time limit for filing and serving an affidavit of records in actions other than divorce, parentage and maintenance, matrimonial property and domestic relations actions is

(a) for the plaintiff, within 90 days of service of the first statement of defence and within 90 days of service of any subsequent statement of defence that raises new issues, and

(b) for each defendant, within 90 days of service of the statement of defence by that defendant. ${ }^{104}$

l.ate filing of affidavit of records

188.1(1) On application, the Court may grant an order under subrule (2) if it is satisfied that

(a) a case is complex,

(b) the volume or location of records requires it, or

(c) other sufficient reason exists.

(2)The Court may grant

(a) an order permitting late, or requiring early, filing or service of an affidavit of records, and

(b) if necessary, an order permitting commencement of examinations for discovery without the filing of an affidavit of records. ${ }^{105}$

Aflidavit of records musi precede discoveries

189 A party is not entitled to conduct an examination for discovery until that party has filed and served an affidavit of records, or is otherwise permitted to commence examination by order of the Count under Rule 188.1(2)(b). ${ }^{106}$

Costs for failing to file aflidavit of records

190(1) A party who, without sufficient cause. ${ }^{107}$

(a) fails to serve an affidavil of records in accordance with Rule 187.

(b) fails to serve an affidavit of records in accordance with an order of the Coun made under Rule 188. I. or

(c) applies under Rule 188. I after the time for filing an affidavit of records expires

is liable to pay a penalty in costs to the party adverse in interest of 2 times item 3(1) of Schedule $C$, or such larger amount as the Court may determine, irrespective of the final outcome of the proceeding... ${ }^{108}$

(3) Costs imposed under this Rule are taxable and payable forthwith.

Sanctions for failure to file aflidavit of records

190.1 If a party fails to serve an affidavit of records in accordance with Rule 187 or in accordance with an order of the Court made under Rule 188. I, the Court may on application by any other party

(a) strike out all or any of the pleadings of the party in default, or

Ibid., this rule is effective from November 1. 1999 (r. 187(8))

Alta. Reg. 172/99, s. 3.

ibid.

Alta. Reg. 68/2000, s. 4. The 2000 annendment to r. 190 added the words "withoul sutlicient cause." This rule appears to be derived from the CBA's Report of the Task Force out Systems of ( ivil. Austice. supra nole 7 at $45-46$ :

Lawyers and clients should be given a clear financial incentive in achicve carly consensual settlement of their cases and. failing settlement. to work efliciently and in good laith... P'artics and lawyers who do not operate in accordance with these principles ... should face substantıal coms sanctions, generally payable immediately and in any event of the cause. 
(b) impose any other sanction, including an order under Rule 599.1. ${ }^{109}$

\section{New Alberta Rules Compared to Other Canadian JuRisdictions}

There is a wide range of practice in the fourteen Canadian jurisdictions for document production.

\section{A. The Name and Nature of the InStrument of Production}

The instrument of documentary production is variably called the "Answer to Demand for Discovery of Documents," "10 the "Affidavit of Documents," "I the "List of Documents,"112 the "Statement as to the Documents,"113 the "Statement on Discovery,"114 the "Notice of Disclosure"115 and the "Affidavit of Records." 116 Answers, statements, lists and notices, which are required in eight of the fourteen jurisdictions, do not need to be sworn like affidavits, although it seems possible for counsel to apply for an order that the disclosure be sworn.

\section{B. Mandatory versus On Demand Production}

The former Alberta rule calling for an affidavit of documents only upon demand was replaced in 1999 with a rule of mandatory production in all non-domestic relations cases. 117 Generating a formal disclosure document can be very time-consuming, expensive and distressing to the parties. It is difficult to understand how an all-embracing a priori requirement for documentary production in every case, apart from the wisdom of counsel, serves to reduce costs and to simplify and expedite proceedings. Nevertheless, Alberta joined the majority of Canadian jurisdictions to mandate records discovery. Elsewhere in Canada, the rules require disclosure to be exchanged within ten days, ${ }^{118} 30$ days ${ }^{119}$ or 60 days ${ }^{120}$ of the "close of pleadings," which is itself an indefinite or implied event. ${ }^{121}$ In Saskatchewan, the ten day limitation period commences when the statement of defence has been filed;'122 presumably plaintiffs in that province will want to frequently check on filings at the clerk's

Alta. Reg. 172/99, s. 3 and Alta. Reg. 68/2000.

British Columbia and the Yukon.

Manitoba, Ontario, Prince Edward Island, New Brunswick and Canada.

Newfoundland, Labrador and Nova Scotia.

Northwest Territories and Nunavut.

Saskatchewan.

Quebec.

Alberta.

Rule 187(5). It is not clear why these causes of action are dealt with differently.

Manitoba, Court of Queen's Bench Rules, r. 30.03(1); Newfoundland and Labrador, Rules of the Supreme Court, 1986, r. 32.01(1), which stales that must be done so "unless the Court otherwise orders": Ontario, Rules of Civil Procedure, r. 30.03(1); and Prince Edward Island, which adopled Ontario's Rules of Civil Procedure in 1990.

Federal Courl Rules, 1998, r. 223(1).

Nova Scotia, Nova Scotia Civil Procedure Rules, r. 20.10(1). Note that these rules are delegated legislation, made and amended by the judges of the Supreme and $A$ ppeal courts under the authority of the Judicature Act, R.S.N.S. 1989, c. 240, s. 46.

See e.g. Alberla Rules of Court, r. 103.

Saskatchewan. The Queen's Bench Rules of Saskatchewan, r. 212(1). Note that this is delcgated legislation pursuant to the Queen's Bench Act. 1998, S.S. 1998. c. Q-1.01, s. 28. 
office. Alberta now requires the disclosure to be within 90 days of service of the statement of defence. ${ }^{123}$

In only three Canadian jurisdictions, New Brunswick, British Columbia and the Yukon, is production still on the demand of counsel. In Quebec, only "exhibits" that will be introduced in evidence must be disclosed. ${ }^{124}$

\section{SANCTIONS FOR NON-COMPLIANCF.}

There is considerable flexibility in the rules of civil procedure in Canada. Procedural orders are subject to appeal. Most litigators know that virtually any procedural step can be reversed and lapse forgiven. Under the same rationale that parties are to disclose their case before trial and not win by ambush, a party is expected to win on substance and justice of the case and not on procedural sport.

The essence of Canadian rules of procedure, if anything, is to bestow flexibility. Minor breaches, and even major ones, ${ }^{125}$ are routinely excused. Bad form itself is not a consequential defect. ${ }^{126}$ Most jurisdictions save procedural steps by starting with the principle that non-compliance shall be treated as an irregularity and does not nullify a proceeding, a step taken or any document or order made in the proceeding. ${ }^{127}$ Most rules have a provision such as "the court may, only where and as necessary in the interest of justice, dispense with compliance with any rule at any time." 128

In the context of flexibility, discretionary general sanctions for procedural breaches are wide-ranging. They include judicial discretion to set aside a proceeding, either wholly or in part; set aside any step taken in a proceeding, or a document or order made in the proceeding; allow an amendment to be made; dismiss the proceeding or strike out the statement of defence and grant judgment; or make any other order it thinks just. ${ }^{129} \mathrm{~A}$ party's rights can be revoked or suspended in the discovery process, a penalty in costs may be awarded and a party or one's lawyer may be held in civil contempt.

Alberta's r. 190, which strictly imposes double costs on a non-compliant party, is unique in Canada. ${ }^{130}$ In all other jurisdictions there are no specific mandatory sanctions for the late

Rule 187(6).

Quebec, Code of Civil Procedure, Art. 331.2.

In some rules, such as the Federal Courr Rules, r. 57; The Queen's Bench Rules of Saskatchewan.. 217(4): and Alberta Rules of Court, r. 560. even where the wrong type of originating document is filed it is not a nullity, only an irregularity.

Sec e.g. Alberia Rules of Court, $\pi$. 561, 561.01

Federal Court Rules, r. 56 and British Columbia, Supreme Court Rules, r. 2(1). Nute that the Yukon adopted the British Columbia's Supreme Courr Rules.

See Ontario, Rules of Civil Procedure. r. 203: Rules of Civil Procediure. Supreme Court of Prince Edward Island, r. 2.03: British Columbia. Supreme Court Rules. r. 2.03: and Maniloba. Court of Queen's Bench Rules, r. 2.03. All jurisdictions have an equivalent relieving provision. Sec e.g. Alberio Rules of Court, r. 558.

Newfoundland and Labrador. Rules of the Siupreme Court.s, r. 2.01(2)(a-d).

These costs are payable forthwith (r. $190(3))$. The court can also strike out pleadings and impose other and further sanctions (r. 190.1). The Northwest Territories and Nunavut are the next most strict. These territories have extensive rules regarding procedural delay. See. r. 327 et seq. Yet, even they do not 
filing of disclosure. All jurisdictions enforce the duty to disclose by general sanctions that might apply, subject to judicial discretion on the merits, to any other procedural noncompliance. Sanctions for procedural non-compliance are considered in the context of each set of facts. Alberta also has these general sanctions for non-compliance with the rules, and counsel may seek to add further remedies to double costs. The court considers "sufficient cause" in determining whether to impose any general penalty for procedural noncompliance. ${ }^{131}$ Apart from Alberta's $r$. 190, there is no right to any remedy, and especially there is no a fortiori right to a remedy without consideration of the merits or prejudice in the case.

\section{Critical Analysis of Rules 187 and 190}

The rollout of the new 1999 rules $^{132}$ was met with both confusion ${ }^{133}$ and criticism from the profession. In the first month, the Law Society of Alberta's Memorandum contained a piece entitled "New Discovery Rules":

Al the Rules of Court Committee meeting an December 8, 1999, issues and concerns raised by the profession concerning the new discovery Rules ... were addressed. The following reflects either recommended changes of the Committee to the new Rules or comments which otherwise, hopefully, address the majority of the concerns raised... may require some amendments or fine tuning to the new discovery Rules ... Chief Justice Moore has also indicated that, although the new Rules contain onerous sanctions, it is fully anticipated that the Court of Queen's Bench will adopt a cautious and practical approach to their enforcement.

The replacement of the Notice to Produce system with an automated timeline for production of affidavits of records has generated a mixed response from members of the Bar. Although some counsel preler the autoniation and penalty for late filing as a means for expediting the litigation process, mary are concerned with the effectiveness of the new Rules for various reasons. Some members noted that where the locations of

come close to the harshness ol Alberta's $r$. 190.

11. Sec e.g. Manitoba, Court of Qucen's Bench Rules, r. 30.08(2).

11: Hon. Dave llancock, "The Alberta Courts in the 2 Ist Century" Newstefter (Canadian Bar Association. Alberta Branch and the Law Society of Alberta) 25:3 (August 2000) 2 at 2: "The Court of Queen's Bench and the Rules of Court Committe have worked very hard to implement rules responding to many of the recommendations of the Systems of Civil Justice Task Force. Examples include the new rules which have recently come into force on expert evidence, examinalions for discovery and summary trials."

i' Some people assumed that these new rules on timeliness were mostly to address concerns about the "new ceonomy" and relevance. Sec e.g. Peter J. Forrester, "New Rules Re: Production of Records: Just When You Thought You Had the Rules All Figured Out, They Cliange" in Rules of Cour for Legal Sitpport Siaff (2000) (Edmonton: Legal Education Suciety of Alberta, 2000) at 1 (emphasis added]:

While the old production rules generally worked, they had two signilicant faults. One was they no longer made sense in the context of the new economy, which deals with all sorts of new ways of disseminating informalion or creating records. Secondly, cases have become more and more complex and record oriented, and there was a need to revisit what really should be produced in a lawsuit. As such. the new Rules attempt to correct hese foults by redefining what a record is, by creating a new process and new documents for production, by creating new time lines for production. and new. penalties to enforce these provisions 
documents requested for production are numerous, the 90 day limil is tno narrow. Moreover, many indicated that counsel routinely ignored the Rule. ${ }^{134}$

Poelman and Bodnar note that the rules have "become more detailed, complex, and codelike with each amendment." 33 "They added "given the fact that there is no flexibility with respect to the ninety day period outside of seeking leave of the court, these sanctions are severe, even draconian."136 Justice Watson in Wagner v. Petryga Estate would call them "tough rule[s] with a disciplinary approach intended to expedite civil proceedings ... for the larger benefit of the administration of civil justice."137 Stevenson and Côté characterized $r$. 190 as "an important reform, a cornerstone of the 1999 reforms. It is mandatory."138

\section{A. ARguments AGainst RULE 187}

\section{THE RECOMMENDATION OF THE: RULES OF COURT PROJECT}

In the fall of 2001, the Rules of Court Project consulted the legal community widely. The Discovery and Evidence Committee considered the automatic time limit for filing and service of the affidavit of records and the strict double costs sanction for non-compliance.

The Committee noted confusion as to whether the 90 day period could be enlarged on agreement of counsel without a consent order, ${ }^{139}$ and observed that in some instances parties are now having to file an affidavit of records where they would not otherwise choose to do so, and the 90 day period can operate to delay the proceedings, compared to the former ten day period. ${ }^{140}$

The "somewhat divided"1+1 Committee proposes maintaining the current 90 day rule, and specifically adding to the rule that counsel may agree to enlarge or abridge that period or the court may make an order to that effect. This minor revision is thought to satisfy the above concerns, primarily by relying upon the goodwill, common interests in expedition and cost efficiency and professionalism of opposing counsel. The Committee says:

Presumbably if meaningful setlement negoliations are underway, mosl counscl would agrec not to require a strict adherence to any set timelines for filing of an affidavit of records pending lice outcome of the negotiations. If a party unreasonably requires another party to prepare an aflidavit of records where it is unnecessary to do so. such as where as the matter is unlikely to proceed to discoven, an application may be made to the court. If the court agrees that it is unreasonable to file the aflidavit of records pending the outcome

Consultarion Memorandum No. 12.2. supra note 8 at 6-7. lirst para. quoting from tiric Macklin \& Alan Macleod. "New Discovery Rules." Memorandum to Bar (14 December 1999), online: Law Society of Alberta <www.lawsocictyalberla.com/l.SA_Archives/index.cfm?page=arcdiscoveryrules.ctm\& rev $=1.0>$.

Glen H. Poelman \& Eugene J, Bodnar. "Civil Procedure and Practice: Recent Developments" (1999) 37 Alta. I. Rev. 909 at 910

lbid. at 926.

(2001), 292 A.R. 320 at paras. 2, 26 (Q.B.)|Wagner].

Supra note 26 at 150.

Consultation Memorandum No. 12.2. supra note 8 at 7.

Ibid. at 8 .

Ibid. at 11 . 
of some other event (such as negotiations), costs may be awarded against the party who had acled unreasonably. ${ }^{142}$

We think that this may operate in some cases, but the nature of adversarial proceedings is that relatively few counsel will volunteer to give up the chance of a costs windfall for their clients early in the process. They are unlikely to agree that ongoing negotiations are equally "meaningful," and probably not meaningful enough to abandon a chance on double costs in the race down the 90 day track. Under the current interpretation of this rule, where double costs are granted without any consideration of merit or degree of delay beyond 90 days, it is difficult to envision an instance where a court would conclude that insisting on compliance is "unreasonable." It is one's right to look to compliance with the rule and it is hard to imagine one being penalized in costs for doing so.

\section{FURTHER CONCERNS WITH RUIE 187}

The new r. 187 mandates "every party ... to file and serve on all other parties an affidavit of records." There is no exception for this legal requirement, ${ }^{143}$ but it is itself an exception to the demand approach in civil procedure rules generally. ${ }^{144}$ Other than the need to file and serve a pleading in response to a statement of claim to avoid default judgment, there is no other similar prescription in the Rules comparable to the command of r. 187 on the parties, which compels the affidavit of records. ${ }^{145}$

In a plaintiff-driven civil process model, steps are initiated by the parties that are presumably cost and procedure effective. Oral examinations for discovery can be limited or waived, as they are not similarly mandated, yet they are at least as important as documentary discovery. Certain facts can be admitted or not. Motions and appeals are elective. For example, the rules on "Compromise Using Court Process"146 and "Money in Court"147 are voluntary. If the Rules mandate an affidavit of records and reinforce the mandate with conquering sanctions, ${ }^{148}$ which is an exception to the general approach of the Rules, rationally there should be a particularly potent rationale for doing so. Such a clear rationale is not evident here. Although 11 out of 14 Canadian jurisdictions now automatically mandate production of records, it is not obvious why they made the change. There is no overwhelming evidence that the demand model in use for decades was not efficient and effective. ${ }^{149}$

\section{lbid. at $11-12$.}

The time for filing and serving may be enlarged by agreement or order, but (absent acquiescence in adversarial proceedings) the affidavit must be filed to avoid double costs and other sanctions.

Most Canadian jurisdictions, however, have the same rule.

It is ironic that even with a $\$ 25.000$ monetary jurisdiction, the Provincial Court of Alberta, tasked as it is "to ensure an expeditious and inexpensive resolution of the matter" does not do the discovery phase at all, and especially does not follow many of the Alberia Rules of Courr. Sec. Provincial Courl Act. supra nole 4, 5. 8(2).

Alberta Rules of Courr, Pant 12.

lbid., Part 12A.

Consider, for example, the difliculty in striking out a pleading under r. 129 or obtaining summary judgment under Part 11.

"The deadline for production oflen passed without the documents being produced, or any consequence occurring. Further, sometimes documents would not even be produced before or at the Examination for Discovery, and as such a lawyer on one side would be conducting the examination blind" (Forrester. supra note 133 at 1-2). This concern. however. would be addressed by one applying to court for a remedy. 
Some actions in superior trial courts are smaller claims for which a lengthy or mandatory discovery will not be warranted. Some matters, which may be minor in terms of interest or remedy sought, cannot be heard in Provincial Court. ${ }^{150}$ They have to be brought, if at all, in the Court of Queen's Bench where they are subject to the mandatory filing rule.

One is left to consider how moving from a system where the affidavit is producible upon demand to a mandatory delivery system is less expensive and less time-consuming. It is counterintuitive that mandatory filing and service will ever lead to lower litigation costs. It has already been pointed out that the 90 day period (contrasted with the former ten day period) may actually hinder expedition more than facilitate it. We point out below that the mandatory requirement to file and serve, combined with the mandatory double costs penalty, will inadvertently create around it a new focal point for rancor between the costs that will likely increase both delays and costs.

Any legal command to merely file and serve a document runs the risk of putting quantity over quality, and of making form more important than substance. The mandate for an affidavit of records within a strict time period will inevitably produce some incomplete affidavits because time is more important than content. We have seen some very late "amended" or "supplementary" affidavits of records, despite no allowance for them in the Rules. Does this constitute non-compliance with the Rules and a right of the other party to double costs and other sanctions? The practice of nominally filing and later re-filing to avoid the double costs penalty causes delay and increases costs and confusion. If the purpose of the time sensitive rule is to ensure complete documentary disclosure within an early fixed time period, that objective seems defeated by filing a nominal affidavit within the time prescribed and further true and complete affidavits months or years later. This question has not been judicially settled, but we believe any affidavit after the 90 th day would be non-compliant with both the letter and the spirit of the rule, in a way that could attract double costs and other sanctions.

The discovery stage is one of the most time-consuming, anguishing and expensive stages of the lawsuit. There is a reasonable likelihood that, in numerous lawsuits, the major and perhaps only actual dispute will swirl around petty procedural issues and questions, where the quibbling between the parties is over a few thousand apparently non-discretionary dollars. Discovery itself is generally very hard on the parties. It is subject to little effective judicial supervision and can be used to bully and torment the other party. We believe that no part of it should be mandated.

In the context of mandatory documentary production, it is valuable to review the number of instances in which the parties proceed through civil trial in Alberta. The national data demonstrate that times to trial are very long, and there are extremely few civil trials, when compared to the volume of lawsuits initiated. For statements of claim filed in 1994 in Ottawa. 4.8 percent reached the trial ready stage and only 1.1 percent reached a trial hearing. ${ }^{141}$ Different types of disputes varied in their rates of progression to the trial ready and trial stages of the civil process. Debt collection cases represented 25 percent of trial ready cases 
and 13 percent of cases proceeding to trial. ${ }^{132}$ Only 0.3 percent of divorce petitions resulted in a trial. ${ }^{133} \mathrm{~A}$ mere 0.1 percent of application-initiated cases reached the trial ready stage. ${ }^{1.44}$ Four out of five of these cases were residential tenancy matters. ${ }^{155}$

The Alberta statistics of lawsuits that proceed to trial are comparable. Parties to civil actions that were filed in 1991 had a 2.2 percent chance of reaching trial by the end of $1997 .^{156}$ Just over 6 percent of the total number of cases initiated in the reference year in Calgary ever went to a trial ready list, with 1.8 percent proceeding to trial. ${ }^{137}$ In Edmonton, the comparable percentages were 4.9 and $1.6 .^{158}$

One can view this phenomenon of the courts being used essentially only for pre-trial procedures with a more current statistic of trial incidence. In the year from 1 April 2002 to 31 March 2003, a total of $5 \hat{3,415}$ civil actions were commenced in the Court of Queen's Bench of Alberta. During that same time period, only 604 trials took place. This represents an overall trial production or "capture" rate of 1.1 percent. ${ }^{159}$ For the next year, 1 April 2003 to 31 December 2003 , the same rate was even lower at 0.96 percent. ${ }^{160}$

The function of the courts is to provide trials - the locus of dispute settlement - and are for disputants who pursue their claims. Reforms have primarily sought to reduce delays, costs and hostilities on the way to, and through, the courtroom. Very few litigants see a trial judge today. Trials are not the major work of the court. Pre-trial procedures and case processing are the business of the court.

Virtually all plaintiffs abandon the formal lawsuit process after they invoke it. The rules of procedure should serve to encourage settlement, but only upon the grounds of merit. In other words, litigants should be abandoning the courts because they attain the satisfaction of civil justice outside of them, not because they cannot attain civil justice from the courts. We believe that rules such as 187 and 190 , which do not focus the parties as much upon the merits as they focus them upon procedures, may risk sending plaintiffs in frustration and hopelessness away from the courts in which they started.

Further research might help to explain why, but one might expect several causes are responsible for this phenomenon. The plaintiff will file a lawsuit for many reasons other than to obtain a judgment ultimately. The claim may serve to vent frustrations. The plaintiff may seek a remedy, such as attention to the dispute, an apology, recognition, understanding, respect or standing to be heard, which are all objectives that cannot be ordered after a trial. A lawsuit may be a signal of resolve and it may be contextually strategic in its timing and purpose. It may be filed before full appreciation by the plaintiff of the limits of the judicial

lbid. at 29.

Ibid. al 21

Ibid. at 30.

Jbid.

This statistic was gained from personal communication with Ms. Michelle Summer. Assistant 10 Chief Justice of Alberta. Court Services Branch.

Ibid.

Ibid.

Jbid.

Jbid 40,181 civil actions were commenced and 387 trials were held 
process and of the law. It may be to intimidate, humiliate or embarrass the opponent. One may sue without seeking a trial. A lawsuit, such as a counterclaim, may be defensive to buy time or to serve as a counter measure. ${ }^{161}$

Most counsel experience what these statistics tend to confirm - that a statement of claim is another instrument in the negotiation tool kit. Accordingly, a sound policy of procedure would be to facilitate settlement and abandonment of formal suits by minimizing ways in which the Rules themselves become the focus of the dispute and maximizing focus on the merits of the dispute.

To conclude the criticism of $r$. 187, the mischief alleviated by the automatic discovery of records procedure ${ }^{162}$ is not only elusive, but the compulsory step comes with various associated costs to the quick, inexpensive and courteous resolution to the merits of the disputes. In other words, it may do more harm than good. Most litigants do not proceed to trial. The effectiveness of the judicial and legal systems to them will be evaluated on their pre-trial experience. It is not obvious that r. 187 leads to better civil justice than its predecessor. We recommend a return to the former $r$. 186 demand practice model.

\section{B. ARGUMENTS AGAINST RULE: 190}

The law reports do not tell of many concerns or problems with the longstanding affidavit upon demand model and the general remedy approach to non-compliance. If the Rules Committee was concerned with delays at the affidavit of records stage, we do not know what data supported that concern. This data might have been obtained from court clerk records, statistics and surveys of lawyers.

The uniquely Albertan minimum double cost penalty imposed, virtually without discretion and assessed without any regard to prejudice and the merits of the case, represents a drastic change from the pre-1999 document discovery regime. ${ }^{163}$ There are more reported cases, and within them more criticism, in the last few years than in the several decades preceding under the former practice.

\section{THE RECOMMENDATION OF THE RULES OI: COURT PROII:CT}

The Committee cited "many concerns" with this new provision, including judicial angst. ${ }^{\text {tht }}$ Even "the Committee had differing views on this issue."

An analogy applies to criminal law where an aecused might plead not guilty to negotiale a plea bargail or buy lime, or guilty only to dispose of the malter.

Curiously, r. 187(5) retains the old approach in the new rule. In "divoree, parentage and maintenance. matrimonial property and domeslic relations actions" an affidavit of tecords need only be filed upon demand of the other party.

Note that there are even shorter dates for filing documents, see, for example, five days ( $r$. 67), eight days (r. $130(2)(b))$ and 10 days (rr. $7 \mid(2.1)$ and $56(4)$ ), but none of these is accompanied by a strict penalty for non-compliance equivalent to r. 190. 
The Committee was uneasy about a procedure that "if no penalty was prescribed, the onus would fall on the innocent party (in other words, the party bringing the application) to show why it should be entitled to costs." 166 One queries why that would be a concern since that was the case under the former rule for many decades and the rule still appears to be working well in every other Canadian jurisdictions. No clear case seems to have been made by the Rules Committee in 1999 or by the ALRI Committee in 2002 for changing the old rule to the new mandatory costs rule. This former rule of judicial discretion in granting costs or other sanctions against a late filer on proof of cause is consistent with the entire design of the civil procedure rules in Alberta and elsewhere. ${ }^{167}$ The Rules generally call on the applicant to prove its case for any sanction. We suggest that the Committee was in error to use the single exception in the Canadian rules as the baseline upon which to consider reform.

The Committee added that the other "problem is that the lack of a specified penalty may also lead to inconsistent decisions as to amounts of penalties for failing to file the affidavit of records pursuant to the requirements in the Rules." ${ }^{163}$ This minimum mandatory penalty is an exception in the procedural system. Presumably, all other cost sanctions are "inconsistent decisions" based on discretion on the merits of each case. One might reasonably argue that a filing on the 91 st day with no prejudice should lead to a different penalty than not filing at all. A policy of consistent mandatory penalties in non-consistent circumstances needs to be justified.

The recommendation of the Committee is that "there be a specific onus on the party who failed to file the affidavit of records within the prescribed time to show why they should not incur a prescribed penalty." ${ }^{169}$ This reverse form of onus to avoid liability for double costs essentially leaves $r .190$ intact because late filers may, and most likely will, attempt to show "sufficient cause."

The Committee added that "the Court should retain the discretion to either increase or decrease this amount in the circumstances"170 That would, however, not be a retention of discretion, but an enlargement of discretion. The current language of r. 190(1) only authorizes a greater penalty, which is presumably the basis for judicial interpretation that the double costs penalty is mandatory. The Committee's proposal would be to make it easier for judges to reduce the penalty.

\section{FURTHER CONCERNS WITH RULE 190}

In the remainder of this article, we present further arguments against retention of $\mathrm{rr} .187$ and 190. In the conviction that this anomalous rule does more harm than good to the causes of expedition, cost minimization and justice on the merits and civility in civil proceedings. We conclude with a recommendation to rescind these rules and to reinstate their predecessors. The ALRI Discovery and Evidence Committee identified some concerns with

in. See for example, in Alberta, r. 558, which stiputates that "non-compliance with the Rules ... which may be ... amended or otherwise dealt with." 
r. 190, but did not recommend any material change to it. Below we propose to set out more disquiet with this rule and conclude by recommending that it be rescinded.

\section{a. Should the Costs Penalty be Paid to the State?}

In Wagner, Watson J. was emphatic that these penalties were to the benefit of the state administration of justice:

Moreover, a key object of the Rule appears to be the larger bencfit to the administration of civil justice by using sharp discipline to ensure that parties do not drag their feet. The terminology of the Rule suggests that the Court does not want to encourage parties to think waiver of that larger public interesI can be assumed....

This Rule, tough as it is, was not created solely for the benefit of the pastics but for the larger benefit of the administration of civil justice. ${ }^{171}$

If this is true, it follows that the penalty is regulatory and should be paid directly to the state. To pay it to the adversary, who need not establish any prejudice, and for whom most often none can be shown, is to give that party an early windfall that can be used against the paying party. This windfall gives rise to several further concerns described below. One might expect that if the double costs penalty were not personally received by the timely party, they would never make a r. 190 application. That would not necessarily follow because they might stil] want to take a step that would cost the opponent money and they would be entitled to costs for the application. In any event, the timely party could grant the indulgence of forgiving the penalty - this would be a well received contribution to goodwill between the parties. If one foregoes the penalty because one does not personally obtain the windfall, this is not in itself a perversion of the course of justice.

\section{b. Meaning of "is liable to pay a penalty"}

Generally, there is discretion in the hands of the judge for awards of costs. ${ }^{172}$ If the judge does not have discretion, and the mandatory costs are punitive, the order is tantamount to a quasi-criminal fine. Does the phrase "is liable to pay a penalty" in r. 190(1) mean "shall be ordered to pay a penalty," or does it confer judicial discretion? One notes that the counterpart language in the Streamlined Procedure, ${ }^{173}$ enacted at the same time, and the double costs sanction when money is paid into court for settlement. ${ }^{174}$ Both use mandatory language and leave less apparent judicial discretion than "is liable to pay a penalty."

Given the exceptionally punitive nature of r. 190, and its indifference to actual delay or prejudice, it is a reasonable judicial approach to give the defaulting party the benefit of the rule's application especially in minor defaults. Justice Watson did not think so in Wagner:

"' See Alberia Rules of Court. Part 48. r. $670(1)$ which states "A party ... tailing to comply with a deadline fixed by the Rules or by order, shall be ordered to pay costs in any event and forthwith, except for special reason." 
The grammatical and ordinary sense of the word "liable" in the Rule might be read in a manner akin to the appearance of the same word in a penalty provision under the Criminal Code of Canada were it not for the fact that the Rule expressly goes on to say "or such larger amount as the Court may determine, irrespective of the final outcome of the proceeding". This signifies that double costs is the minimum. ${ }^{135}$

With respect, it does not necessarily follow that the stipulation of a minimum level of penalty alone would bind one to impose it.

\section{c. Unwarranted Exception to the Principle of Discretion on the Merits}

Aside from whether the Alberta courts need have concluded that "liable to pay" inescapably means that they had no discretion in the matter ("must" and not "may"), and whether "sufficient cause" was intended to be almost impossible to establish, it is clear that these interpretations of the rule are now established law. ${ }^{176}$

In the Alberta Court of Appeal decision of Johnston v. Bryant, Hunt J.A. stated orally:

Rule 190(1) states that if the deadline for filing is missed "without sufficient cause", the party "is liable to pay a penalty in costs to the party adverse in interest of 2 times item $3(1)$ of Schedule $C$., or such larger amount as the Court may determine, irrespective of the final outcome of the proceeding."

Although costs are generally a matter of discretion, the chambers judge does not appear to have considered the wording of R. 190(1). There is no evidence that Gosling had sufficient, or any, cause for not filing in time. The purpose of this new rule is to ensure that litigation proceeds in an expeditious manner... Its language gives a chambers judge only the discretion to find that suflicient cause for missing the deadline lias been established, or to impose a larger amount in costs than that specifically mentioned in the Rule.

In this case, the penality for late filing ought to have been imposed by the chambers judge, regardless of the oulcome of the proceedings.... R. $190(1)$ is mandatory. ${ }^{17}$

The Johnston decision on $r .190$ is a conquest of application over reason, an approach that has been long denounced in civil procedure. ${ }^{178}$ The interpretation and application of this rule, especially, should have been better reasoned because it is such a departure from the approach taken by the other rules and by our conventions of judicial decision-making. ${ }^{170}$ The overarching approach to adjudicating civil procedures and costs is dressed in discretion after consideration of the specific merits and accompanied by the routine practice of excusing noncompliance for which no prejudice can be shown. If that policy is departed from by the

17s Supra note 137 at para. 43.

17. Graybowskl, supra note I at para. 5; Wagner, ibid. at paras. 18, 19. 24, 26.

in (2003), 327 A.R. 378 at paras. 15-17 [Johnston].

17\% See e.g. Bank of Hamilton v. Baine (1888), 12 P.R. 439 at 442 (Ont. C.A.), Armour C.J.: "Having regard to modern ideas and modern legislation in matters of practice and procedure, such rules must now be applied only in the interest of and for the advancement of justice, and not in support of ancient technicality" and Wales (Princess of) v. Liverpool (Earl) (1818), I Wils. Ch. 118, 37 E.R. 51 at 56 (Ch.), Lord Eldon: "There is no general rule ... with respect to the practice of this Court that will not yield when the clear and obvious demand of justice requires."

17. For example, it is hard to understand how issuing the wrong originating document is forgivable as a mere "irregularity" and often passes unsanctioned (r. 560), yet we justify forthwith double costs for missing a day on an aftidavit that no one needs. 
imposition of minimum punitive mandatory sanctions, one would expect the rationale for such a departure to be compelling. Sentences in Canadian criminal law are always discretionary, ${ }^{180}$ and proportionate ${ }^{131}$ in the circumstances of each case. Minimum sentences, in particular, are restricted. ${ }^{182}$

Alberta courts could have built more flexibility into $r$. 190. Both the double costs penalty (r. 190) and other sanctions (r. 190.1) can be applied in any case. The affidavit of records would not appear to justify this disproportionate kind of assault on a party. The thrust of Part 24 , generally dealing with "delay in prosecution of action," emphasizes prejudice. ${ }^{183}$ "This legislative and judicial stringency does not match the value, if any, to be gained from $r .190$. Parties may settle and abandon their suits because of the operation of this rule alone without having merits addressed. The rule provides a further basis for dispute and distraction.

In Honside $v$. Wong, ${ }^{184}$ the plaintiff had been lenient towards the defendant who filed a statement of defence nearly a year after service of the statement of claim. Then plaintiff's counsel inadvertently failed to file an affidavit of records on time as he had moved offices, which generated much confusion, and subsequently went on vacation. Master Quinn said:

II is with great reluctance that I grant the cross motion of the defendants for an order requiring the plaintiff to pay costs of $\$ 2000.00$ forthwith [for failing to file the affidavit or records within 90 days].

There are two reasons for this reluctance, namely:

1. I believe counsel for the plaintiff thought he would be shown lenience by counsel for the delindants in reciprocation for the lenience he had shown in the matler of the filing of the statement of defence

2. A penalty of $\$ 2000.00$ in the circumslances of this case is in my view excessive, and to paraphrase Gilbert and Sullivan the penalty does not fit the "crime". II"I was not proluibited from setting a lower penally I would have set it at $\$ 500.00^{185}$

A one hour violation of an empty affidavit is treated in the same way as an essential affidavit that was never filed. Empirical evidence was not generated to prove the affidavit of records was the main cause of unnecessary litigation delay when the rule was enacted and none is present now to demonstrate that the new rule is curative of delays in any manner. This should have been the standard to be met in implementing this rule that constitutes such an extraordinary departure from the overall policy of the Rules. Serious doubt lingers as to whether this rule expedites proceedings at all. A jurisdiction should be slow to adopt a rule that forces one party to strictly pay money over to another party with no consideration of the merits. The general sanction to strike pleadings operated effectively to get the affidavit of records furnished. 


\section{d. Part 13: A Patchwork of Rules}

Part 13 of the Alberta Rules of Court is now more labyrinthine than ever before. Many general rules are qualified by exceptions, which lead to uncertainty, confusion and more court appearances. The objectives of these rules are not clear as they appear to mix evidence, sanctions, requirements, allowances and presumptions. A court can exempt one from the application of many rules, except r. $190 .{ }^{186}$ It is hard to rationalize the ordering and numbering of some sections. ${ }^{187}$ Inspection ${ }^{188}$ is essentially "production." ${ }^{.199}$ Inspection access must be endorsed on the affidavit, and assumes a single inspection opportunity, but this is not common practice. ${ }^{190}$ Limiting inspections might have done more for expedition than the 90 day rule. This open-endedness and requirement to apply to the court for access contributes to the confusion and increases delays from court applications. ${ }^{191}$ The requirements when multiple parties are involved have yet to be settled. ${ }^{193}$

There are several other related defaults in the discovery rules that can delay procedure, but for which there are no sanctions equivalent to mandatory double costs. These include obtaining a court order where a party did not produce a record in compliance after a valid demand ${ }^{193}$ or where one did not list it in the affidavit. Those documents may be used in court, without onerous double costs sanctions. ${ }^{194}$ The practice, not authorized in the Rules, of unilaterally issuing a "supplementary affidavit" seems to override rr. 187, 190 and 197. This practice has not been judicially considered to date in light of the new discovery rules, but it appears to be procedurally unsafe.

Any party may apply for a "further and better affidavit" from the opponent, but the applicant is not entitled to an award of double costs. ${ }^{195}$ The procedural requirement to produce "an" affidavit of records (and the corresponding punishment for failing to do so within the strict time permitted) is more stringent than the sanction for not doing it well or not following other rules such as production. One questions the benefit of an affidavit

For example, in r. 192(2)(1)(a) language is typical: "... not apply if the court otherwise orders." See e.g. r. 191 and r. 195 seem tautological. Rule $188(1)(a)$ and r. 194 are hard to reconcile. Rules 188 ef seq.

Rule 194.

See e.g. r. 188: "there must be endorsed on the affidavit of records a notice stating (a) the fime when the record may be inspected. bing no later than 10 day's aficr the da) the affidavit is served, and (b) the place at whicl the record may be inspected" and r. 195 "to give notice of a time for inspection" [emphasis added]. However, there may be more than one inspection (r. 188(3)). Presumably, a party will stop granting access and the onus will fall to the secking party to obtain an order under $r$. 195.

See e.g. rr. 188.1, 189.1, 195.

In Sustrik v. Alberla AG-Bag Lid., supra note 2, there were several statements of defence filed four months apart and affidavits of records in response. Where a subsequent statement of defence raises new issues, an affidavit of records would have to be filed in addition to the one previously filed (ibid. at para. 20). Justice Lee refused to impose the double costs penalty and said: " $\Lambda$ s to the seriousness and importanee of the problem created in the case at bar. I conclude that this entize issue las been a needless waste of everyone's valuable resources and time" (ibid. at para. 23). "In fact the purpose of the Rules here is to expedite matters. In this case the parties have spent most of their time arguing about these points, while ignoring even the necessity for setting down Examinations for Discovery. The administration of justice and the interests of the parties is not being advanced by these Applications" (ibid. at para. 26).

Rules 191, 197(1).

Rule 197(1).

Rule 196. 
secured within 90 days, if production itself can be denied to the opposing party or if the affidavit can be readily upgraded without sanctions.

The affidavit of records is much like the pleadings in that it does not in itself advance the litigation as much. It is a sworn set of lists. It is the inspection of these documents and the oral discoveries that are instrumental in moving the suit forward. Production and inspection of documents is on the demand model. ${ }^{196}$ There is no requirement that all inspection take place within a certain period of time after service of the affidavit of records.

\section{e. The Phenomenon of "Chasing One's Losses"}

Civil procedure seeks to advance substantive justice by developing a system that is accessible, expeditious and affordable. If the parties do not go through trial (and most of them do not), how can the rules best facilitate substantive justice without a trial? The answer is in getting the parties to quickly and inexpensively settle their dispute. Rule 190, double costs without merits paid forthwith, ${ }^{197}$ seems counterproductive to early and inexpensive settlement because of the psychological phenomenon of "chasing one's losses."

There is an instinctive hazard in a rule that forces - very early in the process - one side, regardless of the merits of the case or the prejudice suffered by the other side, to pay a punitive sum of money to the other. While there is risk and some element of gambling in every lawsuit, the double costs award under $r$. 190 is unearned. Such an automatic award of double costs or more is not merely a windfall to the recipient. The lucky windfall can be used to finance further steps that might not have otherwise been taken. One now has extra or disproportionate bargaining power over the other side. It may take away some of the sting of the lawsuit early on and mislead the recipient of what is yet to come. The windfall may be an early public symbol of success and advantage. Ordered by the court, it can appear to falsely add credibility to one's position.

The impact of having to pay double costs forthwith early in the proceedings can be even more controlling on the payor. One will be embarrassed, if not chastened, by paying punitive costs to the adversary on a technicality. Being ordered to pay the other party money to fight against you may be viewed as an insult upon insult, especially when the other party can obfuscate and delay in many other ways and there is no equivalent sanction. By what rationale of fair play should one be forced to pay the opponent double costs for having missed one inconsequential deadline, but suffer (without an equivalent remedy) that same opponent to miss numerous other deadlines or to be abusive in any variety of other procedural ways? Without obviously advancing the ultimate merits of the case, the double costs award may be a court-sent signal that procedural regularity counts more than substantive justice.

The mandatory award of punitive costs on a basis unrelated to the merits, prejudice or justice in a case is likely to produce the behaviour known in the gambling business as 
"chasing one's losses." This well-documented phenomenon, ${ }^{198}$ even occasionally described as arousal, "is clearly a constellation of cognitive, emotive ... and behavioural components associated with continuing to bet and increasing the size of bets." 199 Convinced that the judicial system may also be an adversary, the payor of double costs may re-commit to, and persist in, the litigation for a longer period in order to vindicate oneself and to at least prevail in recovering those costs ultimately. Paying double costs to the other party may be seen as an investment in the litigation that, at a minimum, must now be regained. A party forced to pay any money to the other will more tenaciously pursue recovery of these costs in the action than otherwise. In the process, also, one might not expect the unhappy loss chaser to demonstrate goodwill cooperation in the balance of the proceedings.

\section{f. The Intensification of Hostility and Litigation Around These Rules}

When a procedure is compulsory, it becomes the subject of considerable litigation itself. It is foreseeable that many resources will be poured into developing a formidable jurisprudence on every aspect of $\mathrm{rr} .187$ and 190 . We see this already happening. The number of motions and appeals will increase, not reduce. This is akin to a body of cases interpreting the rules on denials, punitive proceedings and striking pleadings, under such rules as 129 and 244.1. Pleadings, however, are struck far less frequently than double costs awarded.

The CBA Task Force noted that delays and higher costs often stem from interlocutory applications and appeals. These rules do nothing to reduce the number of pre-trial trips to the courthouse; rather they make pre-trial sparring more likely. Under these new rules, there are more thresholds for a remedy. There is continued uncertainty of meaning and application of these new rules. Punitive double costs will encourage parties to litigate even small amounts on principle. For example, what use should be made of other remedial provisions in the rules, starting with r. 187(7)?

There are many questions that remain to be answered under the rule requiring "every party ... to file and serve on all other parties an affidavit of records." The tenuous status of the supplementary affidavit has already been highlighted. While the rule speaks of "party" responsibility for "an affidavit," one presumes that the duty is directed at causes and issues in dispute. Accordingly, does a party, say a defendant who is also a plaintiff by counterclaim, have to file an affidavit of records in respect of the defence and a separate affidavit for one's counterclaim? A good argument under the wording of the rule and its purpose can be made

John O'Connor \& Mark Dickerson, "Definition and Mensurement of Chasing in Off-Course Betting and Gaming Machine Play" (2003) 19:4 Journal of Gaunbling Studies 359 [O'Connor \& Dickerson. "Definition and Measurement"]: Nancy M. Petry, "Moving Beyond a Dichotomous Classification for Gambling Disorders" (2003) 98 Addiction 1673; Richard J. Rosenthal. "Distribution of the DSM-IV Criteria for Pathological Gambling" (2003) 98 Addiction 1674; Mark Dickerson, "Gambling: A Dependence Without a Drug" (1989) 1 Int. Rev. of Psychiatry 157: Jim Orford, "The Fasciuation of Psychometrics: Commentary on Gerstein ef al." (2003) 98 Addiction 1675: Jolin O'Connor \& Mark Dickerson, "Impaired Control Over Gambling in Gaming Machine and Off.Course Gamblers" (2003) 98 Addiction 53: Mark Dickerson. John Hinchy \& John Fabre. "Chasing. Arousal and Sensation Secking in Off-Course Gamblers" (1987) 82 British Journal of Addiction 673. 
for the requirement to file two affidavits or the need at least to clearly indicate that the one affidavit shall serve for both causes. ${ }^{201}$

The many loopholes, exceptions and qualifiers in the new rules occasion less certainty and more litigation. ${ }^{202}$ If one is faced with paying double costs, one is more likely to quibble about when the limitations period started and ended and what is a technically proper "affidavit of records." If the affidavit can be argued to be in inadequate form in some way, the opponent might want to make a case for double costs.

The court has also found fault with the rule's claim to expediting litigation. In Govenlock v. Govenlock, Master Breitkreuz noted "tremendous hostility" between the parties and he questioned the effectiveness of $r$. 190:

I suppose the framers of Rule 190(1) thought that the gravity of the consequences of failure to comply with Rule 187 would result in the litigation process moving forward more quickly thereby resolving the dispute between the parties earlier than if the rule did not exist. My experience in applications under Rule $190(1)$ is that the very application aceelerates the intensity of the animosity between the parties, and whatever possibilities there were of resolving the dispute short of a trial would practically cease to exist. Assuming the purpose of the rule is as I have stated, I think it has failed nuiserably to serve that purpose in this case. ${ }^{203}$

The Master preferred to exercise discretion in the circumstances, ${ }^{204}$ which implied that any penalty in costs should be proportional to the breach, and awarded costs in the cause. An appeal to the Court of Queen's Bench was partially allowed. ${ }^{205}$ Justice Lee noted that r. 190 "was designed to be draconian"206 and agreed that "without sufficient cause" grants the discretion "to excuse a party from the imposition of the rule where it would be harsh and inappropriate relative to the breach." ${ }^{1207} \mathrm{He}$ refused to impose the double cost penalty on grounds that the affidavit of records had been filed, the delay was minor and the case had not been affected in any material way. He determined that costs in the total amount of $\$ 500.00$ should be awarded against the respondent. This was for the non-compliance, the application before the Master and the appeal.

Similar concerns were expressed by Lee J. in Sustrik v. Alberta AG-Bag Lid:

In Sustrik v. Alberia AG-Bag Lid, supra note 3, one of the defendants had never filed an aflidavit of records. Master Funduk reluctantly deemed the affidavit of records of another defendant to be that of the defaulting defendant, even though there as a failure to "style the Affidavit of Records both as to Jim Rakai and Alberta AG-Bag Lid., and the documents for each are identical" (ibid. at para. 74).

A classic example of this is Litemor Distributors (Edmonton) Lud. v. Midn'est Furnishings and Supplic.s Lid. $2001 \mathrm{ABQB} 235$. The plaintifr applied for costs against the delendant for late filing of the affidavit of records. The defendant brought a similar cross-action. Master Quinn granted the application for costs against the defendant, but the order was stayed. The cross-application was adjourned when the plaintilf applied for late filing and service of the affidavit under $r$. 188.1. The cross-application was latter dismissed. Subsequent subnissions demonstrated that the plaintiff lad delivered the affidavit on time Master Quinn subsequently lifted the stay and imposed double costs against the defendant. (2001), 284 A.R. 396 al para. 7 (Q.B.) [Govenlock].

Ibid. at para. 13.

Govenlock v. Govenlock (2001). 284 A.R. 399 (Q.B.)

lbid. at para. 10.

lbid. at para. 12 
The Respondent's Brief filed ... is in many places incomprehensible and needlessly complicated throughout in my respectful opinion.

The Bill of Costs in this matter is $\$ 2,500.00$. The problem created by the late filing of the Aftidavit of Records is clearly not a $\$ 2,500.00$ problem.

In fact the purpose of the Rules here is to expedite matters. In this case the parties have spent most of their time arguing about these points, while ignoring even the necessity for selting down Lxaminations for Discovery. The administration of justice and the interests of the parties is not being advanced by these Applications. ${ }^{208}$

Justice Watson in Wagner ${ }^{209}$ would not be deterred by concern about increased hostilities. He stated:

A court cannot withhold consistent application of such a Rule for such a reason. To do so would either stultify the Rule, or would create serious unpredictability in its application. Indeed, it could lead to a conclusion that the only time the Rule would apply would be when the parties are engaged in a non-personal civilized form of litigation and are prepared to accept benignly the consequences of their procedural lapses. Where the parties are vehemently at odds, the Rule might be considered inapt by this submission. ${ }^{210}$

It is not only true that animosities are inflamed by this rule and that leads to more nasty contention. In the first five years of this rule, the Alberta courts have been widely disparate in their interpretation and application of it. In the recent case of Balogun v. Pandher, ${ }^{211}$ for example, Veit J. concluded that the mere fact of the plaintiff's self-representation contributed to the subjective complexity in the case. In determining whether the plaintiff had sufficient cause for the late filing, Veit J. stated: "Mr. Balogun met the burden of establishing that that there is 'sufficient cause' for him to have failed to file his affidavit records in a timely way: the cause is the complexity of the proceeding relative to Mr. Balogun's ability as a selfrepresented litigant."212

\section{g. Other Stages of Litigation Yield Greater Promise for Expedition}

One of the main rationales given for an automatic 90 day limitation period for the delivery of the affidavit of records is that it is effective to keep the litigation moving along with the momentum of the pleadings. We believe, aside from the concern that it may actually impede the progress of the lawsuit, it achieves little of the intended effect of expedition.

The only requirement under the rules is for an affidavit of records to be delivered within the required time period. There is no limitation period for the use of that disclosure or for the commencement of the oral discoveries, which can come "at any time"213 after "procur[ing] an appointment for the examination from the clerk." ${ }^{214}$ There are no strict cost sanctions for

Supra note 2 at paras. $24-26$.

Supra note 137.

lbid. at para. 25.

(2003), 349 A.R. 390 (Q.B.) [Balogun].

Ibid. at para. 27.

Rule 203(1).

Rule 204(1) 
delays on other time-limited steps prescribed at the same stage in the litigation. ${ }^{215}$ Absent any timeline ordered by the court, one has five years in order to do any "thing ... that materially advances the action." 216 Over six years after the enactment of that "mandatory," "drop dead" rule, the Alberta Court of Appeal found that "there still seems to be some uncertainty about" it, calling for further clarification. ${ }^{217} \mathrm{~A}$ procedural system that required more than one material advance of the lawsuit every five years would contribute far more to expedition than the $\mathbf{9 0}$ day period for the affidavit of records.

The parties are free to informally enlarge the time, and frequently do so, such as in the case of 15 days in which to deliver a defence. It is common for a chambers judge to grant a generous extension of time upon application and even impose costs on the defending party who was insisting upon performance according to the Rules. There are other stages in a lawsuit that present far better opportunities to expedite proceedings than the affidavit of records. These include the one year period in which to file the statement of claim, ${ }^{218}$ renewable once for up to three more months, ${ }^{219}$ and the room in the limitations legislation itself. ${ }^{220}$ Many rules specifically allow the extension of the prescribed time to take a step in the action. ${ }^{231}$

\section{h. Costs Under What Schedule C Column?}

In their discretion, judges choose a Schedule $C$ column for costs assessment. Rule 190(1) does not fetter this discretion. The judge could impose double costs on anywhere between column one to column five of item $3(1)$, an award between $\$ 1000$ and $\$ 3000$. This amount can be increased by any multiplier that judge determines. If there is more than one defendant named, but only one defendant remaining in jeopardy, it would be anomalous for the costs to be leveraged into a higher column.

\section{i. A Rule 190 Endorsement on Pleadings?}

Since 1993,,$^{222}$ all statements of claim must have the r. 88(1)(e) notice and warning, in plain lay language:

\section{To (NAME OF DFFENDANT)}

You have been sued. You are the Defendant. You have only 15 days to file and serve a Statement of Defence or Demand of Notice. You or your lawyer must file your Statement of Defence or Demand of Notice in the oflice of the Clerk of the Court of Queen's Bench in Alberta. You or your lawyer must also leave a copy of your Statement of Defence or Demand of Notice at the address for service for the Plaintiff named in this Statement of Claim.

21" Sec e.g. selection of a corporate representative within 5 days after a demand (r. 200.I(I)).

216. Rule 244.1(1)

:17 Alberla v. Morasch (2000), 250 A.R. 269 at para. 2.

six Rule $11(1)$.

il. Rules 11(2), (5).

2:1) Limitations $A C t$, R.S.A. 2000 , c. L-12, s. 6.

221 Rules II, 66(4), 243,2, 244.4(g), 548, 549, 736.7(2), 81, 847(c).

222

Alta. Reg. 160/93. 
WARNING: If you do not do both things within 15 days, you may automatically lose the law suit. The Plaintiff may get a Court judgment against you if you do not file, or do not give a copy to the Plaintiff, or do either thing late.

This is a legally mandated defendant protection device at the beginning of the lawsuit. A similar backer notice to, and from, defendants should be mandated, warning each party about the time-limited delivery of the affidavit of records. ${ }^{223}$ Some notification to inform parties of the filing and service requirements, and the potential penalties for non-compliance, would likely reduce incidents of non-compliance and the consequent delays, costs and hostility related to applications and appeals and thereby more effectively accomplish the purpose of r. 190. It would reduce the use of the rule for procedural advantage that might even deprive a party of the opportunity to vindicate the claim. ${ }^{224}$ Similar notice requirements are in place to enforce contractual waivers of rights.

\section{j. "Gotcha" and Clean Hands}

It is ironic that discovery itself is calculated to eliminate the substantive unfairness of surprise, ambush and other "gotcha" events, where one party triumphs over the other merely on a procedural technicality. Rule 190 enshrines a "gotcha" event because it imposes a mandatory penalty on what may be a small time violation that is likely to have had no consequence to the proceedings. The punishment does not repair the missed deadline and it does not teach or correct future procedure.

The beneficiary may use this quick procedural victory as a bargaining tool to ultimately thwart the prosecution of the lawsuit on its merits. A "gotcha" victory is rarely countenanced in civil litigation, much less sanctioned by the legal system, because it violates the ethic against taking advantage of another under the sporting model of litigation. "Gotcha" tactics lead to a decline in respect for the system of civil justice administration and it is inexplicable why the Rules would make new room for it.

After the "gotcha" tactic is triggered, considerable energy is directed against its operation in order to reverse it. The "gotcha" tactic shifts the lawsuit from substance to tactical procedure. Ultimately, after all the procedures have been invoked the only payment that may have been ordered between the parties is that one paid double costs to the other, a result that no one had expected. Rules of procedure should have less impact on the outcome of the case than the substantive merits. as he was unaware of the timeframe for filing an aflidavit of records and the penalties for noncompliance. The respondent was a teacher who, upon service of the statement of claim, filed a statement of defence within the 15 day time limit, maintaining that the notice to defendant and warning on the backer of the statement of claim had prompted the compliance. Upon service of the affidavit of records. the respondent examined it and the accompanying counsel letter for a similar time limit notification. finding none in either. The cense supports an argument for some form of notification of the time requirements and sanctions regarding affidavits of records. Had the respondent been informed of the time requirements and sanctions for non-production, the chances for non-compliance would have been reduced significantly. The respondent's actions before and after scrvice of the notice of motion demonstrated a grasp of the imponance of time limits, a willingness and intention to comply with the rules. and that non-compliance arose primarily out of unfamiliarity with the rules.

:24 Self-represented parties are most likely to be caught by this rule. See e.g. Balogun, supra note 211 . 
These double costs do not compensate. They are not what is fair - they are only concerned with punishing. It is difficult to predict the course the lawsuit will follow after punishment, but anecdotal experience of judges and counsel shows that the results are not what was intended. 225

We suggest that any party claiming a right to receive an award of double costs should itself have a "clean hands" type of record of conduct in the litigation. This equitable standard is not prescribed in r. 190 but it may be implied. For example, one party may purport to terminate the agreement to extent time to deliver the affidavit. ${ }^{226}$ The list of overall equitable considerations would include: the size and nature of the claim and whether it is likely to be addressed substantively; the number and complexity of the records; whether the party claiming has benefited from interpretative grace or has been responsible for other defects in form or procedure in the action; and the conduct of counsel.

23 This may be a common scenario. The authors personally know of a recent Alberta defamation action for minor damages filed in the Court of Queen's Bench, because the Provincial Court was withoul subject matter jurisdiction. The plaintiff named one party as a defendant for strategic reasons (to cease certain conduct). without the intent to proceed to trial. The plaintiff believed that he had suffered an egregious wrong, but he had no appetite for further full length legal process. The co-defendants failed to respond and were noted in default. The plaintiff and nominal defendant had no contact, even through counsel. The statement of defence of this defindant was served three days out of time by fax on the 18 th day after the statement of chaim was served on the plaintift. The aftidavit of records, misspelling parties names and listing 14 records, was served during stumener vacition on the $9 /$ st day afler the statement of elaim. technically willin time under r. 547. The plaintill was not aware of $r$. 190. The next (and in many ways, the first) contact from the lawyer for the defendant was the notice of motion claiming double costs, after which the plaintiff's alfidavit of records. listing 7 ilcons. was quickly filed and served. The plaintilthad no intention of proceeding except to eventually withdraw the claim against the defendant. He was not planning on any discovery of the defendant. and the latter never inspected any documents disclosed nor expressed any interest in oral discovery. The defendant did not suggest they suffered any prejudice owing to the late affidavit. Defendant's counsel reliused to make a courtesy telephone call to the plaintiff to request an affidavit of records from the plaintifl. or even to identily himself as counsel witls carriage of the malter. The plaintiff believed, and argued, that the streamlined procedure governed. The defendant's notice of motion lor the order for double costs wis defeclive on its face. Defendant's counsel spoke in crror ahout that defect before the Masier al the hearing. and laler apologized privalely to the plaintiff for doing that. Double costs were awarded to the defendant. This altered the course of the litigation. The nexl communication with the defendani's lawyer was "if you will drop your claim. we won't force you to pay these costs." For the next nine months the dispute between the parties focused entirely on the $r .190$ award of double costs. Services of notices were challenged, a request to stay execution pending appeal was denied, an adjournment to hear the appeal in special chambers after Christmas was opposed and the defendant took the position that the appeal was also out of time. Documents were faxed by the defendant to the plaintifl's work address, through his employment supervisor's oflice without pernission. Delendant's counsel called the plaintiff's family at home, despite having been given a differeut telephone number to use. The plaintiff appealed the order and was ordered to pay anolher $\$ 500$ in costs. Counsel for the defendant admitted that he had no instructions to even talk about the merils of the case with a view to settlement. The procedural skirmisls around teal people living with real concerns continued as the defendant garnishecd close to wo and a half times the tolal costs award. Almost four years after the cause of action arose, and wo and a half years after the statement of claim. no one had yet addressed the substance of the dispute. The double: costs order had become the only issue. The plaintiff formally abandoned the action against the defendant, which he was always planning to do, in return for the defendant's agreement to return the costs award. Predictably, yet ironically, no one actually cared about the content of any affidavit of records or the underlying dispute - no record was ever seen. 


\section{k. Increased Incivility in the Litigation Bar and Professional Ethics}

It is said that "civil litigation should not be an oxymoron." There is a trend in other recent Alberta rules to discourage sharp practice ${ }^{227}$ and the taking unfair advantage of the opponent. ${ }^{228}$ Yet rr. 187 and 190 do nothing to improve civility between lawyers. They generate more need to rely upon the goodwill of opposing counsel more often. The rules encourage parties to obtain favours and consents for extensions of time from their adversaries. ${ }^{229}$ They call for a greater cooperation that cannot be legislated and, in default, for more court orders. One party's consent is power over the other which, for no particular reason, it is unwilling to relinquish in adversarial proceedings.

The question arises as to whether counsel ethically has to consent to an enlargement of time to file the affidavit because it might be professionally unreasonable not to do so? Is it taking unfair advantage on the part of the other lawyer to fail to remind one of this 90 day limitations period? The Alberta Law Society Code of Professional Conduct applies:

\section{Relationship of the Lawyer to Other Lawyers}

[Rule| 3. A lawyer must not take advantage of a mistake on the pan of another lawyer if to do so would obtain for the lawyer's client a benefit to which the client has no bona fide claim or entitlement.

[Commentary]: ... a defendant in a lawsuit has a legal right to insist that proceedings be brought within a certain period of time. Accordingly, while the missing of a limilation date by plaintifl's counsel may be an obvious mistake, the defendant's lawyer does not violate Rule $\$ 3$ by allowing the limitation period to expirc.

[Rule] 4. A lawyer must agree to reasonable requests hy another lawyer for extensions of time, waivers of procedural formalities and similar accommodations unless the clicut's position would be materially prejudiced.

[Commentary]: An important element of the duty of courtesy to other lawyers is willingness to accede to reasonable requests that do not affect the client's position in any material respect. What is reasonably in any given case will depend upon all the circumstances ... cooperation of this naturc assists in expediting the clients' business. Forcing onc's opponent to make a court application that will surcly be granted not only antagonizes opposing parties, but causes additional delay and expense for both sides.

It is not sufficient justification for a refusal to cooperate that a client has so insteucted the lawyer, since a client's instructions can never override the ethical ubligations of counsel. $A$ lawyer must seriously consider continuing to act for a client who is adamant about refusing cooperation after all the implications of so doing (including the additional delay and expense mentioned above) have been fully explained. ${ }^{230}$

:2) Some give the court special powers of relief, of an equitable estoppel nature. See e.g. r. II(9). which allows for an extension of time to serve a statement of claim when misled by opposing counsel. Or granting consent, e.g. r. 135 and generally enlarging time in r. 548.

:2. Rule 549 states: "The time for delivering, amending or filing any pleading, answer or other document may be enlarged by consent in writing svithout application to the court." A lawyer might also give an undertaking not to seck the $\mathrm{r}$. 190 remedy.

241 Law Society of Alberta, Code of Professional Conduct (Calgary: Law Socicty of Alberta, 1995) at 26, 32-33 [Code] 
Rules 3 and 4 of the Code, and their respective commentaries, did not envision this strict limitations change to the Alberta Rules of Court. Nevertheless, the five intervening years have afforded ample opportunity to address them specifically. The reference in the commentary with respect to Rule 3 only to "proceedings being brought," implies that a lawyer should not take advantage of an opposing counsel's oversight of $r$. 187. Whether one's "client has no bona fide claim or entitlement" in double costs is yet to be tested. Rule 4 of the Code suggests that one might have an ethical right to an extension to file an affidavit of records if one is requested. If these rules of the Code do not limit the application of $r$. 190 and force one's hand when a request to enlarge the time is made under r. 549, they serve to compromise the lawyer and to increase the tension between the lawyer's professional obligations to colleagues and their duties to their clients. ${ }^{231}$

Today there must be an agreement or understanding between counsel regarding time for delivery of the affidavits of records. They will agree or understand that the 90 day period must be met, or that no one will seek double costs, or an extension is granted, or a court order will be made to extend the time. That agreement or understanding must come carly in the proceedings, which may mean that the parties' emphasis might be higher on the aflidavit timeliness than on settlement itself.

I. How to Reconcile Rule 190 with the Streamlined Procedure?

Part 48 of the Alberta Rules of Court and the new discovery rules were enacted about the same time but it appears that their interrelationship was not considered. The interplay between these two sets of rules, one being facilitative and the other being punitive, has yet to be resolved by the Alberta courts. Should one be presumed to apply prior to the other? How can they be reconciled?

If one comes under Part 48, not only are they free from compliance with Part 13 of the Rules, but the discovery process is purposefully limited in Part 48. ${ }^{32}$ This disparate process recognizes that documentary discovery will often be more valuable in large, complex litigation than in small suits ${ }^{233}$ and its abuse is more ruinous in small suits. Nevertheless, $r$. 190 and the streamlined procedure are not adequately integrated. How will one know that one will be accepted into the streamlined procedure before the 90 days pass?

The streamlined procedure applies "to actions when money is claimed in the statement of claim and the total claimed ... is $\$ 75,000$ or less, not including interest and costs." ${ }^{234}$ The parties can file their written agreement with the clerk to invoke the procedure, ${ }^{339}$ and the Court may, in cases where it "considers it appropriate," order the procedure to be used. ${ }^{236}$ Since the court does not act on its own, this order is an outcome of a contested court

2" In practice, when represented by lawyers, parties and their litigation operate outside of the Rules by imutual consent. The Rules come into play when the lawyers refise to cooperate. The formal rules are therefore generally the lowest procedural common denominator. but r. 190 may provide enough incentive to insist on the rule in preference to mutual procedural cooperation. 
application ${ }^{231}$ and there is no time period set out for such an application. Elsewhere in the streamlined procedure, the affidavit of records is due within $\mathbf{3 0}$ days of the service of the statement of defence, ${ }^{238}$ but this deadline may be extended by consent in writing of the parties ${ }^{239}$ and "may be excluded or modified by ... the Court." ${ }^{240}$ A party who misses any streamlined deadline "shall be ordered to pay costs in any event and forthwith, except for special reason." ${ }^{2+1}$ In Robinson (Next friend of) v. Hartridge Training Academy, ${ }^{242}$ Master Quinn exercised unfettered discretion to set the r. 661 cost penalty. ${ }^{243}$ One assumes the cost penalty for delivering a late affidavit of documents can be nominal in Part 48.

In the streamlined case of Spiers v. International Fitness (c.o.b. World Health (lub), ${ }^{2+4}$ plaintiff's counsel was under the mistaken impression that he was under a 90 day time limit for filing affidavits of records, and he consequently failed to comply with the streamlined 30 day rule. When the notice of motion was served for double costs under $r .190$, the affidavit of records was delivered immediately. Master Laycock did not award costs under r. 660 .

The practical problem is reconciling the affidavit of records rules in Part 13 and Part 48. While some actions, under $\$ 75,000$, are presumptively under Part 48 , they can be "excluded" by court order. ${ }^{245}$ In the same way, an action of any size over $\$ 75,000$ can be governed by Part 48 when a court "considers it appropriate." 246 There are no limitation periods for such court applications to add or remove a case from streamlined procedure. ${ }^{247}$ One presumes that any such application should be made, or consent agreement filed, before the Part 13 limitation period expires. Otherwise, the scenario could arise where double costs were ordered to be paid, and paid forthwith, under Part 13. A subsequent application to move the litigation to Part 48 would necessitate a reimbursement of the double costs. A lawsuit that moves from Part 48 to Part 13 by order or consent might also be met with immediate liability for double costs under Part 13. These rules do not contemplate the interaction of these two types of procedures. They need to be reworked, lest this become a race to the courthouse in a case of whoever gets an order first wins.

Where there is no court order or agreement to locate the suit in Part 48, it is not always clear which cases qualify to proceed under Part 48 . The $\$ 75,000$ "total claimed" ceiling does not reference against whom that claim is made. In multi-party suits, there may be a claim of $\$ 40,000$ against each of two defendants, one of whom may be noted in default. Most Masters will consider the aggregate claim against all defendants in the statement of claim, whether in issue or not, for the $\$ 75,000$ Part 48 ceiling. While r. 659 is silent on its reference point,

$21 \quad$ Rule 673.

23n Rule 661(1)

13. Rule 549.

2a1 Rule 659(1)(2)(b). Sec also, r. 548.

211 Rule 670(1). One notes the diflerence in language in regular procedure $t$. $190(1)$ "withoul sufficient cause" and streamlined procedure r. 670(1) "except for special reason." One might be equally critical of an automalic costs penalty for even nominal untimeliness in Part 48 of the Rutes.

$\therefore \quad 2002$ ABQB 483.

: Sec also Zukiwsky v. Prime, 2002 ABQB 230. Master Quinn.

:1 2001 ABQB I6I.

aN Rulc 659(2)(b).

24. Rule 659(1)(b)

:3 Actions can also be taken out. and added to. by mutual agreemem of the parties (rr. $659(1)(c)$ 659(2)(a)). 
we believe "the total claimed" should refer to the sum of money under active jeopardy in the lawsuit. This is consistent with the spirit of Part 48. ${ }^{248}$ Given the harshness of $r$. 190, for uncertain effect, there should be a judicial inclination to favour use of streamlined procedure when requested by the plaintiff to do so.

\section{m. Rules 216.1 and 599.1 are Adequate for Late Affidavits}

Rule 216.1 purports to address abusive discovery. It provides that when a party "acts or threatens to act in a manner that is vexatious, erasive, abusive, oppressive, improper or prolix" during the discovery process, or where "the expense, delay, danger or difficulty in complying fully with a discovery request would be grossly disproportionate to the likely benefit" the court can modify or waive any right or power in Part 13.249 It is not obvious how this rule interacts, if at all, with r. 190. Perhaps minor non-compliance with the 90 day deadline could be dealt with under r. 216.1. The court in $\mathrm{Wagner}^{250}$ appeared to endorse its periodic use. However, it does not seem appropriate for a court to convert a r. 190 application into one under $r$. 216.1. The interrelationship between these two rules requires clarification. ${ }^{251}$

Rule 599.1, enacted in 1996,2:2 is an effective sanction to deal with those who file affidavits late:

\section{Costs}

599.1(1) Nolwithstanding anything in this Part, where

(a) a party to an action, a counsel acting in respect of an action or any olher person who is involved in an action fails, without an excuse or an explanation that in the opinion of the Court is appropriale, to comply with these Rules or a Practice Note of the Court, and

(b) that failure to comply, in the opinion of the Court, has interfered with or may interfere with the proper or efficient administration of justice

the Court may order that party, counsel or other person to pay to the clerk a penally in the form of costs as determined by the Court.

(2) In making an order under subrule (1), the Court may do one or more of the following:

(a) determine the anount of the costs;

(b) prescribe the time within which the costs are to be paid:

This interpretation is consistent with the language of r. $659(1)$ (a) where "Statement of Clain" is specifically used in the sentence fragment before, relative to money (versus other rentedies) being claimed. This means that "the total claimed" is an independent reference point. The reasonable interpretation of "the total claimed" in $r .659(1)$ (a), where a r. 190 application is made al the outsel of the lawsuit, must be made with a conservative qualification "with respect to this applicant party." If the lawsuit will proceed for less than $\$ 75,000$ against only one delendant, it is appropriate for Part 48 . Why should such a defendant be able to spring out of Part 48 and into a higher Schedule $C$ column with a modest liability exposure'? Not only is the opportunity to use Part 48 lost, but the cosis of proceedings are disproportionately high for a small liability exposure amount. 
(c) prescribe terms or conditions with tespect to the payment of the costs or any other matter respecting the making of the order.

(3) Without restricting the amount of costs that may be imposed under subrule (1), the Court in determining the amount of the costs to be imposed may take into consideration the amount of costs set out in Schedule $C$.

(4) Once costs are ordered to be paid under this Rule, those costs are payable by the person on whom the costs wert imposed

(a) whether or not any settlement was made in respect of the actions, and

(b) notwithstanding any agreement between the parties to the action or their counsel.

If one views the rules of civil procedure as quasi-constitutional in the sense that they should not frequently or radically change, absent good cause to correct a clear mischief, one would be slow to add a mandatory punitive double costs penalty like r. 190. If there is a recent change, as there was in 1996 with r. 599.1, which is comprehensively remedial, it should be given a reasonable time to work before a decision is made that it is ineffective. The threshold should be high to making or quickly adding new amendments.

\section{CONCLusion}

Costs in civil proceedings are generally compensatory. They are not punitive, so as to keep the courthouse doors open to settle parties' grievances. Where double costs are assessed, such as where money has been paid into court to attract a settlement that should have been, the salutary incentive effect on the parties and the civil justice system is preserved. As we have seen, when double costs are awarded on a mandatory basis, without evidence of actual delay or prejudice, early in the proceedings and out of context with other steps, ${ }^{253}$ the result may actually be to cause mischief and defeat the objectives of the rule.

While most affidavits of records will be filed within the 90 day period, one may see how rr. 187 and 190 can operate to the detriment of the civil justice system. Parties can use these rules to penalize the other party and to gain an advantage through an early procedural victory. Under this sporting approach to substantive justice, the litigation may be stalled and costs increased.

The CBA Task Force report attributed discovery delay primarily to the "complexity and number of discoveries and scheduling problems in the [oral] discovery process." proposed greater use of incentives and sanctions to promote the timeliness of civil process. It recommended financial incentives as a means to achieve early settlement of cases, but the first five years of Alberta experience with rr. 187 and 190 show that there may only be nominal compliance with the limitation period for affidavits of records and unforeseen distraction when the time is missed. If the Task Force sought expedition, settlement and reduced costs, these rules may have little (or the opposite) effect.

:si For example, it is unknown why $\mathrm{r} .18 /(5)$ makes some Alberta causes of action on demand disclosure and other causes are on mandatory disclosure.

$\therefore \quad$ Sitpra nole 7 at 43 
The ALRI Rules of Court Project found that 50 percent or more of respondents expressed dissatisfaction with "costs of legal fees; time to resolve legal cases; and the overall legal process," and 40-49 percent were unhappy with "court forms, information available through the court, ease of understanding of the legal process; the trial; the discovery stage; and interlocutory hearing(s)."2ss The fourth objective of the ALRI Project reform effort, to "maximize the rules' advancement of justice system objectives" envisjons "pragmatic reforms to advance justice system objectives for civil procedure such as fairness, accessibility, timeliness and cost effectiveness." ${ }^{236}$ Rule 190 is unlikely to do this; it is a rule that is hard to love.

Rules 187 and 190 are blunt instruments. One might deal with delay as delay, and not select one procedural step to mandate, which may cause little delay overall and back it up with a very harsh rule. The Northwest Territories and Nunavut Rules deal with delay at any stage of an action. The parties have the responsibility to bring an application before the court to determine whether the other party has delayed the action or proceedings. Where the court finds that delay has occurred, these rules establish a range of remedies to address the delay and the problems it has caused to the party making the application. ${ }^{257}$ Thus, these rules grant the court much flexibility in determining how to address delay - - flexibility that enables the court to balance the need for timely proceedings with other important aspects of justice.

Overall, these rules represent an exception to the trend toward alternative dispute resolution and away from "old style" litigation. The ALRI Rules of Court Project should thoroughly review the 1999 amendments on mandatory time limits on affidavits of records and double costs as part of its wholesale review of the Alberta rules of civil procedure. We recommend these 1999 rules be rescinded in favour of the former rules of discovery on demand and judicial authority to address real concerns related to costs and delay. 